\title{
Supramolecular Assemblies Based on Complexes of Nonionic Amphiphilic Cyclodextrins and a meso-Tetra(4- sulfonatophenyl)porphine Tributyltin(IV) Derivative: Potential Nanotherapeutics against Melanoma
}

Antonino Mazzaglia, ${ }^{* \dagger}$ Maria Luisa Bondi, ${ }^{\ddagger}$ Angela Scala, ${ }^{\dagger}$ Francesca Zito, ${ }^{\S}$ Giovanna Barbieri, ${ }^{\S}$ Francesco Crea, ${ }^{P}$ Giuseppina Vianelli, $\|$ Placido Mineo, ${ }^{\perp, \#}$ Tiziana Fiore, ${ }^{\bigcirc}$ Claudia Pellerito, $\bigcirc$ Lorenzo Pellerito, $\square$ and Maria Assunta Costa*, $\triangle$

${ }^{\dagger}$ CNR - Istituto per lo Studio dei Materiali Nanostrutturati, UOS Palermo, c/o Dip. Scienze Chimiche dell'Università di Messina, Viale Ferdinando Stagno d'Alcontres 31, 98166 Messina, Italy

${ }^{\ddagger}$ CNR - Istituto per lo Studio dei Materiali Nanostrutturati, UOS Palermo, Via Ugo La Malfa 153, 90146 Palermo, Italy

${ }^{\S} \mathrm{CNR}$ - Istituto di Biomedicina e Immunologia Molecolare 'Alberto Monroy', Via Ugo La Malfa 153, 90146 Palermo, Italy

"Dipartimento di Scienze Chimiche, Università di Messina, Viale Ferdinando Stagno d’Alcontres 31, 98166 Messina, Italy

${ }^{\perp}$ Dipartimento di Scienze Chimiche, Università di Catania, and I.N.S.T.M. UdR of Catania, Viale A. Doria 6, 95125 Catania, Italy

${ }^{\#}$ CNR-IPCF Istituto per i Processi Chimico Fisici, Viale Ferdinando Stagno D’Alcontres, 37, 98158 Messina, Italy

${ }^{\circ}$ Dipartimento di Fisica e Chimica, Università degli Studi di Palermo, Viale delle Scienze, Ed. 17, 90128 Palermo, Italy

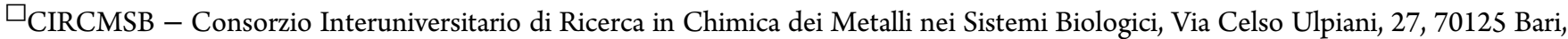
Italy

$\triangle_{\text {CNR }}$ - Istituto di Biofisica, UOS Palermo, Via Ugo La Malfa 153, 90146 Palermo, Italy

Supporting Information

ABSTRACT: Amphiphilic cyclodextrin (ACyD) provides watersoluble and adaptable nanovectors by modulating the balance between the hydrophobic and hydrophilic chains at both $\mathrm{CyD}$ sides. This work aimed to design nanoassemblies based on nonionic and hydrophilic $\mathrm{ACyD}(\mathrm{SC} 6 \mathrm{OH})$ for the delivery of a poor-water-soluble organotin(IV)-porphyrin derivative $\left[\left(\mathrm{Bu}_{3} \mathrm{Sn}\right)_{4} \mathrm{TPPS}\right]$ to melanoma cancer cells. To characterize the porphyrin derivatives under simulated physiological conditions, a speciation was performed using complementary techniques. In aqueous solution $(\leq 20 \mu \mathrm{M}),\left(\mathrm{Bu}_{3} \mathrm{Sn}\right)_{4}$ TPPS primarily exists as a monomer ( 2 in Figure 1$)$, as suggested by the low static anisotropy $(\rho \approx 0.02)$ with a negligible formation of porphyrin supramolecular aggregates. MALDI-TOF spectra indicate the presence of moieties (i.e., $\left.\left[\left(\mathrm{Bu}_{3} \mathrm{Sn}\right)_{3} \text { TPPS }\right]^{-}\right)$that are derivatives of the monomeric species. Spectrofluorimetry coupled with potentiometric measurements primarily assesses the presence of the hydrolytic $\left[\left(\mathrm{Bu}_{3} \mathrm{Sn}\right)_{4} \mathrm{TPPS}(\mathrm{OH})_{4}\right]^{4-}$ species under physiological conditions. Nanoassemblies of $\left(\mathrm{Bu}_{3} \mathrm{Sn}\right)_{4} \mathrm{TPPS} / \mathrm{SC} 6 \mathrm{OH}$ were prepared by dispersion of organic films in PBS at pH 7.4 and were investigated using a combination of spectroscopic and morphological techniques. The UV-vis and emission fluorescence spectra of the $\left(\mathrm{Bu}_{3} \mathrm{Sn}\right)_{4} \mathrm{TPPS} / \mathrm{SC} 6 \mathrm{OH}$ reveal shifts in the peculiar bands of the organotin(IV)-porphyrin derivative due to its interaction with the ACyD supramolecular assemblies in aqueous solution. The mean size was within the range of $100-120 \mathrm{~nm}$. The $\xi$-potential was negative $(-16 \mathrm{mV})$ for the $\left(\mathrm{Bu}_{3} \mathrm{Sn}\right)_{4} \mathrm{TPPS} / \mathrm{SC} 6 \mathrm{OH}$ nanoassemblies, with an entrapment efficiency of approximately 67\%. The intracellular delivery, cytotoxicity, nuclear morphology and cell growth kinetics were evaluated via fluorescence microscopy on $\mathrm{A} 375$ human melanoma cells. The delivery of $\left(\mathrm{Bu}_{3} \mathrm{Sn}\right)_{4} \mathrm{TPPS}$ by ACyD with respect to free $\left(\mathrm{Bu}_{3} \mathrm{Sn}\right)_{4}$ TPPS increases the internalization efficiency and cytotoxicity to induce apoptotic cell death and, at lower concentrations, changes the cellular morphology and prevents cell proliferation.

\section{INTRODUCTION}

Amphiphilic cyclodextrins (ACyD) form established nanoarchitectures for drug delivery. ${ }^{1}$ Nanoassemblies based on
Received: June 10, 2013

Revised: September 18, 2013

Published: October 8, 2013 


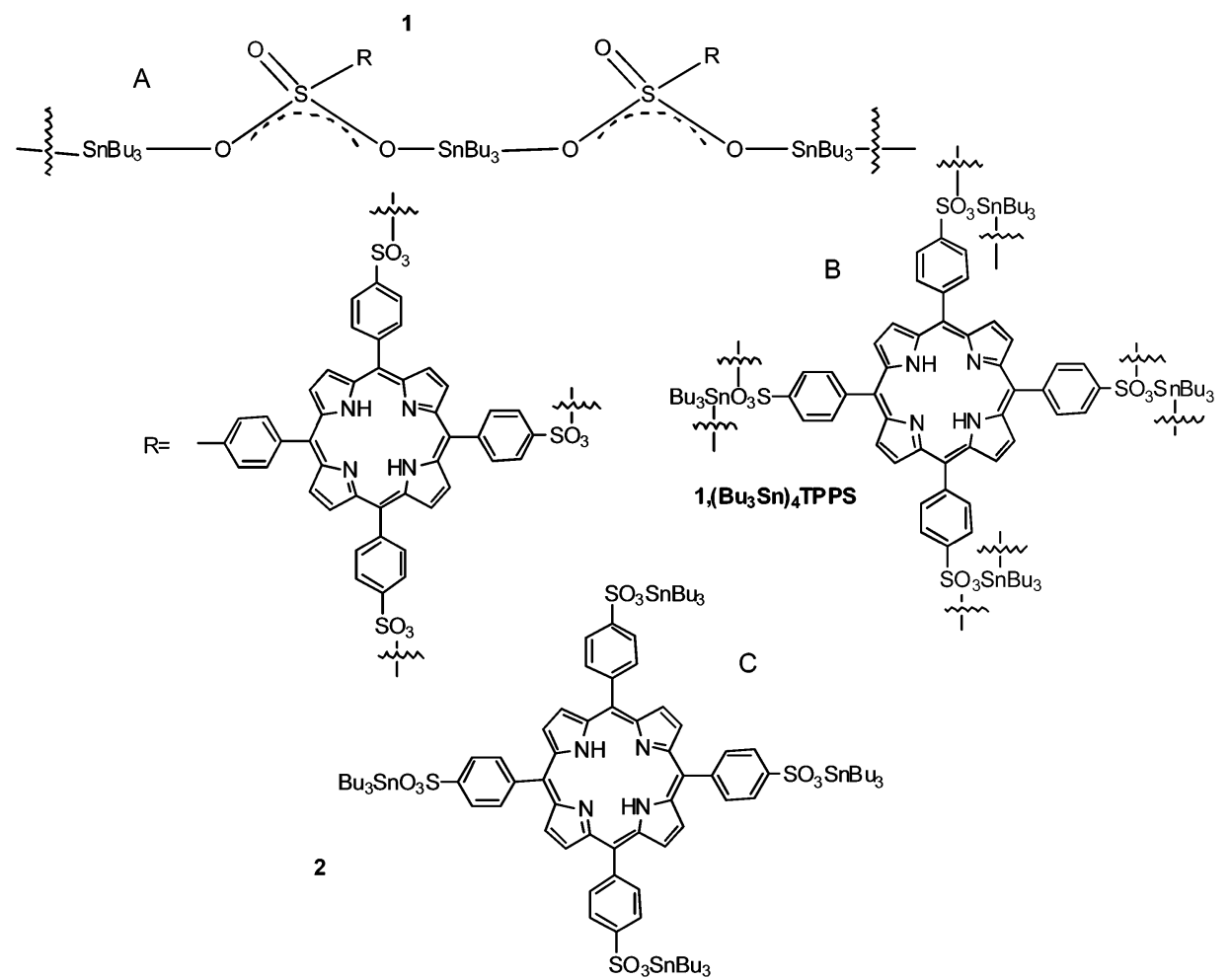

Figure 1. Molecular formulas of coordination polymer $\mathbf{1}$ (A, B), as characterized at the solid state ${ }^{40}$ and of monomer $\mathbf{2}$ (C) plausibly formed in solution (e.g., both 2 and derivative species of 2 have been detected in coordinating solvent as DMSO, EtOH, and up to $20 \mu \mathrm{M}$ in $\mathrm{H}_{2} \mathrm{O}$ ).

ACyD substituted with thioalkyl and oligoethylen glycol chains at the primary and secondary rims of the CyD cavity, respectively, have generated great interest because they can form different nanostructures (such as micelles, micellar clusters, vesicles and nanoparticles) in aqueous solution, depending on both the hydrophobic-hydrophilic balance and the charge of the amphiphile. ${ }^{2,3}$ In vitro, these supramolecular systems are capable of entrapping and delivering conventional anticancer drugs, ${ }^{4}$ photosensitizers, ${ }^{5,6}$ metal nanoparticles, ${ }^{7}$ or combined doses of phototherapeutics for dual action., ${ }^{8,9}$ Moreover, the cationic analogues of these $\mathrm{ACyD}^{3}$ have been proposed as nonviral agents for gene therapy analogous to other nanocomplexes based on CyD. ${ }^{10}$ Unlike other ACyD-based systems, ${ }^{1}$ these assemblies are particularly stable in aqueous and physiological media, and those substituted with short thioalkyl chains $\left(-\mathrm{SC}_{n} \mathrm{H}_{n+1}, n \leq 6\right)$ form homogeneous and clear dispersions upon visual inspection (with average sizes of $\sim 80 \mathrm{~nm}$ ). Covalent modifications with receptor targeting groups ${ }^{11}$ and fluorophoric labels ${ }^{12}$ confer a high potential for targeted drug delivery and drug monitoring, respectively. The versatility of drug encapsulation in nonionic $\mathrm{ACyD}$ nanoassemblies is primarily due to the presence of a thioalkyl-chain-based inner hydrophobic portion, an external hydrophilic region and the macrocycle cavity (Scheme 1), which enable the design of various types of ACyD supramolecular nanocomplexes with different therapeutically important lipophilic or hydrophilic guests. ${ }^{5,13-15}$ Generally, ACyD nanocarriers have sizes compatible with IV injection and have been proposed for optimizing anticancer drug distribution in the body through their potential to extravasate at the level of the tumor defective capillary bed and to deliver the drug to the site of action. ${ }^{4,16,17}$ Therefore, the therapeutic approaches using ACyD nanoassemblies are promising for a large number of diseases, including resistant forms of cancer such as melanoma. Recent investigations in this area have focused on the use of Scheme 1. Sketched View of Nanoassemblies Formation in
Aqueous Solution from SC6OH and $\left(\mathrm{Bu}_{3} \mathrm{Sn}\right)_{4} \mathrm{TPPS}^{a}$

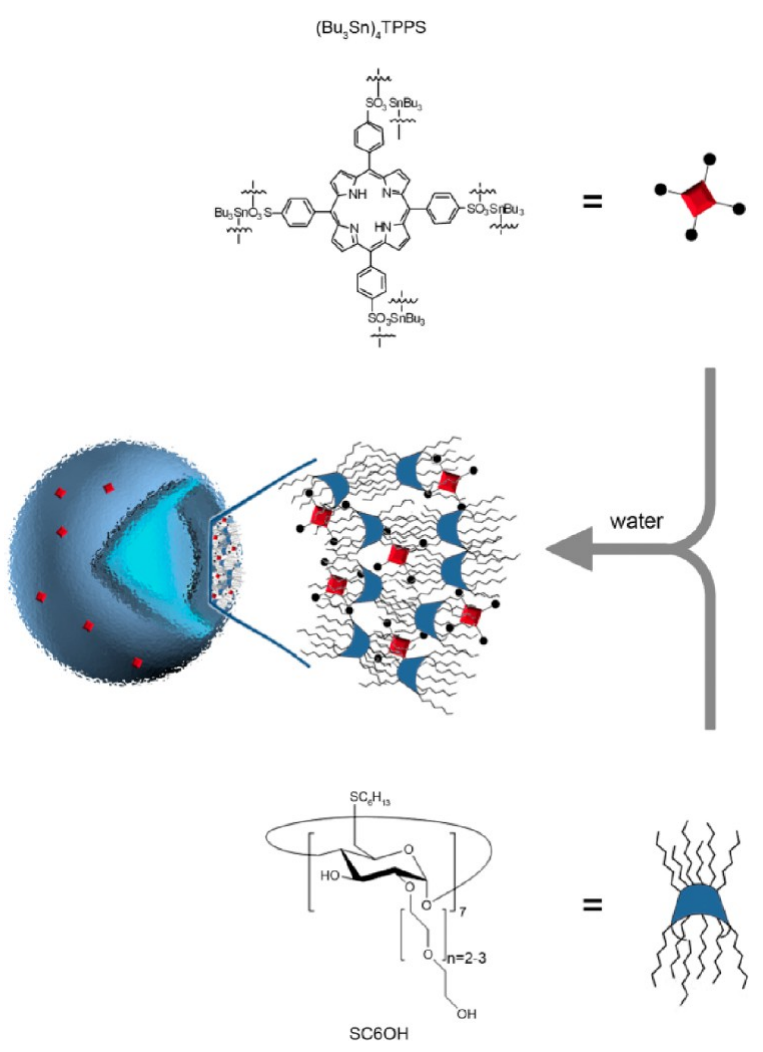

${ }^{a} \mathrm{In}_{2} \mathrm{O},\left(\mathrm{Bu}_{3} \mathrm{Sn}\right)_{4}$ TPPS is plausibly entrapped as derivative species of 2 (i.e., $\left[\left(\mathrm{Bu}_{3} \mathrm{Sn}\right)_{4} \text { TPPS }(\mathrm{OH})_{4}\right]^{4-}$ is the most probable at $\mathrm{pH}=7.4$ as ascertained by speciation, see Figure 2 ). 
polymers, ${ }^{18,19}$ protein-targeted liposomes, ${ }^{20}$ and CyD-based nanoparticles as delivery agents for tumor treatment. ${ }^{21,22}$ Melanoma is the most deadly form of skin cancer and is largely refractory to existing therapies. Over the last thirty years, the worldwide incidence of melanoma has steadily increased more rapidly than that of any other malignancy. ${ }^{23,24}$ The detection and surgical treatment of early stage disease appear to prevent progression in most cases. However, patients with deep primary tumors or tumors that metastasize to regional lymph nodes frequently develop distant metastases.

Currently, the therapies for patients with metastatic malignant melanoma include chemo- or immunotherapy or a combination of the two. ${ }^{25-29}$ However, in the majority of cases, these therapies are insufficient because they can be limited and noncurative.

Another therapeutic approach to melanoma has been photodynamic therapy (PDT), which has been established for certain types of cancer such as lung, esophageal, genitourinary, head, and neck..$^{30,31}$ The PDT uses photosensitizing agents, typically porphyrinoids, which can selectively enter and locate tumors, generating radical oxygen species upon light activation. ${ }^{32}$ However, this therapy is weakly effective for melanoma due to long-term skin photosensitivity and the loss of absorbance during irradiation caused by rapid photobleaching. Moreover, melanin, the pigment produced by melanoma cells, absorbs light in the same wavelength region (400-750 nm) as porphyrinoids, thus, diminishing the photosensitizer effect. ${ }^{33,34}$

Recently, the cytotoxic effects of certain diorganotin(IV) and triorganotin(IV)-meso-tetra(4-sulfonatophenyl) porphine derivatives $\left[\left(\mathrm{R}_{2} \mathrm{Sn}\right)_{2}\right.$ TPPS and $\left(\mathrm{R}_{3} \mathrm{Sn}\right)_{4}$ TPPS $\left.(\mathrm{R}=\mathrm{Me}, \mathrm{Bu})\right]$ were tested on the A375 human melanoma cell line, and of these, $\left(\mathrm{Bu}_{2} \mathrm{Sn}\right)_{2}$ TPPS and $\left(\mathrm{Bu}_{3} \mathrm{Sn}\right)_{4}$ TPPS exhibited high photoindependent cytotoxicity. ${ }^{35}$ In particular, $\left(\mathrm{Bu}_{3} \mathrm{Sn}\right)_{4}$ TPPS blocked melanoma cell proliferation and induced changes in the cellular morphology when used at low concentrations, suggesting cell reprogramming toward a differentiated state. ${ }^{36,37}$

Although the poor water solubility of these porphyrins is highly beneficial in increasing the tumor-to-normal tissue ratio, ${ }^{38}$ as with highly lipophilic chemotherapeutic agents, it significantly limits intravenous administration.

The poor water solubility of $\left(\mathrm{Bu}_{3} \mathrm{Sn}\right)_{4} \mathrm{TPPS}(\leq 20 \mu \mathrm{M})$ and the idea of more selectively targeting the melanoma cells led us to entrap this compound in $\mathrm{ACyD}$ nanoassemblies based on shortthioalkyl-substituted nonionic amphiphilic cyclodextrin ( $\mathrm{SC} 6 \mathrm{OH}$, Scheme 1). We first demonstrate the ability of the $\mathrm{SC} 6 \mathrm{OH}$ nanoassemblies to both encapsulate the $\left(\mathrm{Bu}_{3} \mathrm{Sn}\right)_{4} \mathrm{TPPS}$ and sustain its release under physiological conditions, delivering this drug into highly metastatic A375 cells. Moreover, we demonstrate that $\left(\mathrm{Bu}_{3} \mathrm{Sn}\right)_{4}$ TPPS-loaded SC6OH (Scheme 1$)$ is more effective than the free compound when used at the same concentration. The $\left(\mathrm{Bu}_{3} \mathrm{Sn}\right)_{4} \mathrm{TPPS} / \mathrm{SC} 6 \mathrm{OH}$ nanoassemblies induce the apoptosis of A375 melanoma cells or, when used at lower concentrations, change the cellular morphology and arrest cell proliferation.

\section{MATERIALS AND METHODS}

General Remarks. All solvents were purified and dried using standard techniques. All other reagents were of the highest commercial grade available and were used as received or were purified via distillation or recrystallization when necessary. All solutions used for spectroscopic characterizations were prepared in pure microfiltered water (Galenica Senese, Siena, Italy) and analyzed at $298 \mathrm{~K}$. The heptakis(2-Ooligo(ethylene oxide)-6-hexylthio)- $\beta$ - $\mathrm{CD}$ (SC6OH, $\mathrm{MW}_{n=2}=2763$ amu. $)^{39}$ and $1^{40}$ (formula weight $\mathrm{FW}=2091$ ) were synthesized according to the general procedures. Briefly, $\mathbf{1}\left(\left(\mathrm{Bu}_{3} \mathrm{Sn}\right)_{4} \mathrm{TPPS}, \mathrm{Bu}_{3} \mathrm{Sn}^{+}\right.$ $=\left[\operatorname{tributyltin}(\mathrm{IV})^{+}\right], \mathrm{TPPS}^{4-}=[$ meso-tetra(4-sulfonatophenyl $)$ porphinate $]^{4-}$ ) was obtained as a dark green solid by refluxing methanolic suspensions of $\left(\mathrm{Bu}_{3} \mathrm{Sn}\right)_{2} \mathrm{O}$ (Fluka-Riedel-de Haen, Sigma-Aldrich Company, St. Louis, MO, U.S.A.) and free mesotetra(4-sulfonatophenyl) porphine (Porphyrin Products, Logan, UT, U.S.A.). The solids, recovered via filtration, were recrystallized from methanol or methanol-ether solutions. The formal $\left(\mathrm{Bu}_{3} \mathrm{Sn}\right)_{4}$ TPPS concentrations (conveniently expressed in $\mathrm{mol} \mathrm{L}^{-1}(\mathrm{M})$ ) were calculated using the $\mathrm{FW}$ of the repetitive unit $(\mathrm{FW}=2091 \mathrm{amu})$. The molar extinction coefficients $(\varepsilon)$ in DMSO, ethanol, and $\mathrm{H}_{2} \mathrm{O}$ were measured via UV-vis spectroscopy (Lambert and Beer) by dissolving $\left(\mathrm{Bu}_{3} \mathrm{Sn}\right)_{4} \mathrm{TPPS}(1.5-7 \mu \mathrm{M})$ in the various solvents.

UV-vis, Fluorescence and NMR Investigations. The UV-vis absorption spectra were collected on a Hewlett-Packard model 8453 diode array spectrophotometer using $1 \mathrm{~cm}$ path length quartz cells. Steady-state fluorescence measurements were performed on a Jasco model FP-750 spectrofluorimeter. Emission spectra were collected using an excitation wavelength of $516 \mathrm{~nm}$ in a $1 \mathrm{~cm}$ path length quartz cell. The depolarized fluorescence spectra were measured using ${ }^{41}$

$$
\rho=\frac{I_{\mathrm{VV}} I_{\mathrm{HH}}-I_{\mathrm{VH}} I_{\mathrm{HV}}}{I_{\mathrm{VV}} I_{\mathrm{HH}}+2 I_{\mathrm{VH}} I_{\mathrm{HV}}}
$$

where $\rho$ is the static anisotropy and $I_{\mathrm{VV}}, I_{\mathrm{HH}}, I_{\mathrm{VH}}$, and $I_{\mathrm{HV}}$ are the fluorescence intensities registered with different polarizer orientations ( $\mathrm{V}=$ vertical, $\mathrm{H}=$ horizontal $)$.

The ${ }^{1} \mathrm{H}$ NMR in DMSO- $d_{6}$ was recorded on a Varian $500 \mathrm{MHz}$ spectrometer.

Speciation Studies. Spectrofluorimetric and Potentiometric Titrations. The speciation of $\left(\mathrm{Bu}_{3} \mathrm{Sn}\right)_{4}$ TPPS in pure microfiltered water was investigated using titrations in a Horiba Jobin-Yvon Fluoromax-4 spectrofluorometer equipped with an F-3006 autotitration injector with a Hamilton syringe (mods. Gastight 1725, 250- $\mu \mathrm{L}$ capacity). Aliquots of the $\left(\mathrm{Bu}_{3} \mathrm{Sn}\right)_{4}$ TPPS at various concentrations (up to $1.7 \mu \mathrm{M}$ ) were prepared by diluting $17 \mu \mathrm{M}$ stock aqueous solutions, which were prepared by evaporating a measured volume of an ethanolic solution $\left(\left[\left(\mathrm{Bu}_{3} \mathrm{Sn}\right)_{4}\right.\right.$ TPPS $\left.]=65 \mu \mathrm{M}\right)$ and dissolving the organic film in water, followed by slight sonication. The porphyrin concentration was measured via $\mathrm{UV}$-vis using $\varepsilon_{\mathrm{H}_{2} \mathrm{O}}$. The spectrofluorimetric titrations were performed in the $\mathrm{pH}$ range of $3.7-10.1$ at $\lambda_{\text {exc }}=516 \mathrm{~nm}$, while the emission spectra were collected at $\lambda_{\mathrm{em}}=550-800 \mathrm{~nm}$; the interval between two titrant additions was $180 \mathrm{~s}$. Simultaneous UV-vis titrations in the same $\mathrm{pH}$ range and under the same conditions were performed to assign the emitting species. The potentiometric and spectroscopic data were processed using the Hyperquad 2008 program. ${ }^{42}$ The objective function is given in matrix notation simply as $U=r \mathrm{Wr}$, where $\mathbf{r}$ is a vector of residuals $\left(\mathbf{r}=y_{\text {observed }}-y_{\text {calculated }}\right)$; here, $y_{\text {observed }}$ represents a measurement in $\mathrm{mV}, \mathrm{pH}$, or absorbance, and $\mathrm{W}$ is a matrix of weights. For refinement, the program minimizes the sum of squares of the residuals relative to the different variables. The residuals are ordered with the potentiometric first and the absorbance second. To minimize the objective function, the Gauss-Newton-Marquardt method was used. Different mass-balance equations were defined for each component and were solved using the Newton-Raphson method; the normal equation matrix was used to derive $\partial[H] / \partial \beta k$, where $\beta k$ is the stability constant of the $k^{\text {th }}$ species and $[H]$ is the free proton concentration. More details are provided in the literature. ${ }^{42}$

The following stability constants were input into the speciation model for the diacid species, protonated at the pyrroles of the porphyrinic ring $\left(\log K^{\mathrm{H}}=4.9\right),{ }^{43,44}$ and the hydrolytic species of $\mathrm{Bu}_{3} \mathrm{Sn}^{+}(\mathrm{IV})\left(\log \beta_{\mathrm{MH}_{-1}}\right.$ $\left.=-6.13 ; \log \beta_{\mathrm{MH}_{-2}}=-12.4\right) .{ }^{45}$ The stability constants refer to the general equilibria.

$\log \mathrm{K}^{\mathrm{H}}: \mathrm{L}+\mathrm{H}=\mathrm{LH} ; \log \beta_{\mathrm{MH}_{-}}: \mathrm{M}+i \mathrm{H}_{2} \mathrm{O}=\mathrm{MH}_{-i}+i \mathrm{H}^{+}$, where $\mathrm{H}_{-1}=$ $\mathrm{OH}^{-} ; \mathrm{M}=\mathrm{Bu}_{3} \mathrm{Sn}^{+} ; \mathrm{L}=\mathrm{TPPS}^{4-}$.

MALDI-TOF Mass Spectrometry. The negative MALDI-TOF mass spectra were collected using a thin-layer deposition technique ${ }^{46,47}$ on a Voyager-DE workstation (PerSeptive Biosystem), which utilizes a delay 
extraction procedure $(25 \mathrm{kV}$ applied after $2600 \mathrm{~ns}$ with a potential gradient of $454 \mathrm{~V} \mathrm{~mm}^{-1}$ and a wire voltage of $25 \mathrm{~V}$ ) with ion detection in the linear mode. The apparatus was equipped with a nitrogen laser (emission at $337 \mathrm{~nm}$ for $3 \mathrm{~ns}$ ) and a flash $\mathrm{AD}$ converter (time base of 2 ns).

Nanoassemblies. Preparation. Nanoassemblies of $\left(\mathrm{Bu}_{3} \mathrm{Sn}\right)_{4} \mathrm{TPPS} / \mathrm{SC} 6 \mathrm{OH}$ were prepared at $1: 5$ and $1: 10$ molar ratios $\left(\left[\left(\mathrm{Bu}_{3} \mathrm{Sn}\right)_{4} \mathrm{TPPS}\right]=5 \mu \mathrm{M}\right)$ according to previously reported procedures. ${ }^{48}$ An organic film was dosed by mixing and evaporating aliquots of $\mathrm{SC} 6 \mathrm{OH}$ and $\left(\mathrm{Bu}_{3} \mathrm{Sn}\right)_{4}$ TPPS stock solutions. To yield $1: 5$ and 1:10 molar ratios, $150 \mu \mathrm{L}$ of $\left(\mathrm{Bu}_{3} \mathrm{Sn}\right)_{4}$ TPPS stock solution in EtOH (65 $\mu \mathrm{M}$ ) was mixed with 24 and $48 \mu \mathrm{L}$ of $\mathrm{SC} 6 \mathrm{OH}$ stock solutions in $\mathrm{CH}_{2} \mathrm{Cl}_{2}$ $(2060 \mu \mathrm{M})$, respectively. The organic film was dispersed at $T=50^{\circ} \mathrm{C}$ in $10 \mathrm{mM}$ PBS at $\mathrm{pH} 7.4$ or in $\mathrm{H}_{2} \mathrm{O}$ as specified and sonicated for $20 \mathrm{~min}$ in an ultrasonic bath.

Particle Size Analysis. The mean diameter (size) and width of the distribution (polydispersity index, PDI) of the $\mathrm{SC} 6 \mathrm{OH}$ and $\left(\mathrm{Bu}_{3} \mathrm{Sn}\right)_{4} \mathrm{TPPS} / \mathrm{SC} 6 \mathrm{OH}$ nanoassemblies, respectively, were determined via photon correlation spectroscopy (PCS) using a Zetasizer Nano ZS (Malvern Instruments, Malvern, U.K.) that utilizes noninvasive backscattering (NIBS). The measurements were performed at a $173^{\circ}$ angle with respect to the incident beam and at $25^{\circ} \mathrm{C}$ for each dispersion of $\mathrm{SC} 6 \mathrm{OH}$ and $\left(\mathrm{Bu}_{3} \mathrm{Sn}\right)_{4} \mathrm{TPPS} / \mathrm{SC} 6 \mathrm{OH}$ nanoassemblies using bidistilled water or a $0.9 \mathrm{wt} \% \mathrm{NaCl}$ aqueous solution as the dispersing media. Each dispersion was stored in a cuvette and analyzed in triplicate. The values reported were the averages of three measurements. The deconvolution of the measured correlation curve to an intensity size distribution was accomplished using a non-negative least-squares algorithm.

$\zeta$-Potential Measurements. The $\zeta$-potentials were measured using the principles of laser Doppler velocimetry and phase analysis light scattering (an M3-PALS technique) on a Zetasizer Nano ZS Malvern instrument. Empty $\mathrm{SC} 6 \mathrm{OH}$ and $\left(\mathrm{Bu}_{3} \mathrm{Sn}\right)_{4} \mathrm{TPPS} / \mathrm{SC} 6 \mathrm{OH}$ nanoassemblies were dispersed in bidistilled water or in a $0.9 \mathrm{wt} \% \mathrm{NaCl}$ aqueous solution with the conductivity adjusted to $50 \mathrm{mS} / \mathrm{cm}$. The results are reported as the mean of three separate measurements on three different batches \pm the standard deviation (SD).

Porphyrin Release Kinetics. An isotonic aqueous solution (PBS, 20 $\mathrm{mM}, \mathrm{pH}$ 7.4) was used to obtain a release profile of the porphyrin from the $\left(\mathrm{Bu}_{3} \mathrm{Sn}\right)_{4} \mathrm{TPPS} / \mathrm{SC} 6 \mathrm{OH}$ nanoassemblies at a $1: 5$ porphyrin/ cyclodextrin molar ratio. The quantity of $\left(\mathrm{Bu}_{3} \mathrm{Sn}\right)_{4} \mathrm{TPPS}$ released was determined via UV spectroscopy (UV-1800 spectrophotometer, Shimadzu, Japan) at $413 \mathrm{~nm}$. Briefly, $2.0 \mathrm{~mL}$ aqueous $\left(\mathrm{Bu}_{3} \mathrm{Sn}\right)_{4} \mathrm{TPPS} /$ $\mathrm{SC} 6 \mathrm{OH}\left(\left[\left(\mathrm{Bu}_{3} \mathrm{Sn}\right)_{4} \mathrm{TPPS}\right]=50 \mu \mathrm{M}\right)$ was introduced into a dialysis tube (MWCO $5 \mathrm{KDa}$ ) and immersed in $25 \mathrm{~mL}$ of preheated medium (PBS, $20 \mathrm{mM}, \mathrm{pH} 7.4$ ) at $37 \pm 0.1^{\circ} \mathrm{C}$ under continuous stirring in a Benchtop $80{ }^{\circ} \mathrm{C}$ incubator Orbital Shaker (model 420). At scheduled intervals, solution aliquots $(1 \mathrm{~mL})$ were collected from outside the dialysis membrane and replaced with fresh PBS. The release profiles were determined by comparing the quantity of $\left(\mathrm{Bu}_{3} \mathrm{Sn}\right)_{4} \mathrm{TPPS}$ released as a function of incubation time with the total quantity of drug loaded into the $\mathrm{SC} 6 \mathrm{OH}$. The data were corrected by considering the dilution procedure. A control experiment was also performed to determine the release behavior of the free $\left(\mathrm{Bu}_{3} \mathrm{Sn}\right)_{4}$ TPPS. A suspension of free $\left(\mathrm{Bu}_{3} \mathrm{Sn}\right)_{4}$ TPPS in PBS at $\mathrm{pH} 7.4$ was prepared at the same concentration $(50 \mu \mathrm{M})$ as the drug entrapped in the $\left(\mathrm{Bu}_{3} \mathrm{Sn}\right)_{4} \mathrm{TPPS} / \mathrm{SC} 6 \mathrm{OH}$ nanoassemblies. This suspension was placed in a dialysis tube (MWCO $5 \mathrm{KDa}$ ) and immersed into the appropriate medium. The amount of $\left(\mathrm{Bu}_{3} \mathrm{Sn}\right)_{4}$ TPPS was determined as previously reported.

$\left(\mathrm{Bu}_{3} \mathrm{Sn}\right)_{4}$ TPPS Encapsulation Efficiency. The $\left(\mathrm{Bu}_{3} \mathrm{Sn}\right)_{4}$ TPPS loading in the $\mathrm{SC} 6 \mathrm{OH}$ and the encapsulation efficiency were assessed by dissolving $1 \mathrm{mg}$ freeze-dried SC6OH nanoparticles in $2 \mathrm{~mL}$ of THF and evaluating the UV-vis absorption of the solution at $414 \mathrm{~nm}$ (UV-1800 spectrophotometer, Shimadzu, Japan). To verify the possible interference of $\mathrm{SC} 6 \mathrm{OH}$, unloaded nanoparticles were dissolved in the THF. No $\mathrm{UV}$ absorption was detected at $414 \mathrm{~nm}$. The linearity of the UV response was verified in the concentration range of $0.5-50 \mu \mathrm{g} / \mathrm{mL}\left(R^{2}=0.985\right.$, $\mathrm{LOD}=0.04 \mu \mathrm{g} / \mathrm{mL}, \mathrm{LOQ}=0.20 \mu \mathrm{g} / \mathrm{mL}$ ). The results are expressed as the actual loading percentage (L.C., $\mathrm{mg}$ of drug encapsulated per $100 \mathrm{mg}$ of nanoparticles) and the encapsulation efficiency (EE, the ratio of actual to theoretical loading).

Biological Studies. Cell Culture. The A375 melanoma cell line is a highly invasive cell line from a solid metastatic tumor (ATCC-CRL1619). ${ }^{49}$ The cells were cultured in RPMI supplemented with $10 \%$ heatinactivated fetal calf serum (FCS) and $1 \%$ penicillin-streptomycin $\left(10000 \mathrm{U} / \mathrm{mL}\right.$ and $10000 \mu \mathrm{g} / \mathrm{mL}$, respectively) in $5 \% \mathrm{CO}_{2}$ at $37^{\circ} \mathrm{C}$.

Fluorescence Microscopy Analysis. Cells $\left(4 \times 10^{4}\right.$ cells/well in 400 $\mu \mathrm{L}$ growth medium) were plated on an 8-well Lab-Tek II chamber slide, cultured for $24 \mathrm{~h}$, and treated for 2 or $24 \mathrm{~h}$, depending on the type of experiment, with aqueous dispersions of $\left(\mathrm{Bu}_{3} \mathrm{Sn}\right)_{4} \mathrm{TPPS} / \mathrm{SC} 6 \mathrm{OH}$ at a $1: 5$ molar ratio $\left[\left(\mathrm{Bu}_{3} \mathrm{Sn}\right)_{4} \mathrm{TPPS}\right]=5$ or $0.25 \mu \mathrm{M}$ and with $\mathrm{SC} 6 \mathrm{OH}$ or free $\left(\mathrm{Bu}_{3} \mathrm{Sn}\right)_{4}$ TPPS. After incubation, the cells were fixed as previously described, ${ }^{37}$ and the nuclei were stained with Hoechst 33342 fluorescent DNA-binding dye at $0.01 \mathrm{mg} / \mathrm{mL}$ at room temperature for $10 \mathrm{~min}$. Fluorescence images were recorded using a digital camera system with a rhodamine filter (red emission) to detect cellular localization of the $\left(\mathrm{Bu}_{3} \mathrm{Sn}\right)_{4}$ TPPS and a DAPI filter (blue emission) for Hoechst on a Zeiss Axioskop 2 Plus microscope equipped for epifluorescence.

Cell Death Assay. Cell death was evaluated using trypan blue $0.5 \%$ (w/v; EuroClone), the stain most commonly used to distinguish viable from nonviable cells. In brief, cells were plated into 12-well plates at 1.5 $\times 10^{5}$ cells/well in $1.5 \mathrm{~mL}$ of growth medium. The cells were incubated for $24 \mathrm{~h}$ and then treated with an aqueous dispersion of free $\left(\mathrm{Bu}_{3} \mathrm{Sn}\right)_{4} \mathrm{TPPS},\left(\mathrm{Bu}_{3} \mathrm{Sn}\right)_{4} \mathrm{TPPS} / \mathrm{SC} 6 \mathrm{OH}$ at two different $\left(\mathrm{Bu}_{3} \mathrm{Sn}\right)_{4}$ TPPS doses $(0.5$ or $0.25 \mu \mathrm{M})$, or unloaded $\mathrm{SC} 6 \mathrm{OH}$ at corresponding doses of 2.5 or $1.25 \mu \mathrm{M}$. The adherent and nonadherent cells were pooled after 24,48 , and $72 \mathrm{~h}$, and a small sample of each cell suspension was diluted to 1:1 in trypan blue and counted under normal light microscopy. The effects of the treatment were quantified as the percentage of cell death versus the untreated cells as a control.

Cell Growth Kinetics and Microscopic Digital Imaging. To determine the growth curves, the cells were grown for $24 \mathrm{~h}$ in 12-well plates at $1.5 \times 10^{5}$ cells/well in $1.5 \mathrm{~mL}$ of growth medium and then treated with unloaded $0.75 \mu \mathrm{M} \mathrm{SC} 6 \mathrm{OH}, 0.15 \mu \mathrm{M}$ free $\left(\mathrm{Bu}_{3} \mathrm{Sn}\right)_{4} \mathrm{TPPS}$ or $\left(\mathrm{Bu}_{3} \mathrm{Sn}\right)_{4} \mathrm{TPPS} / \mathrm{SC} 6 \mathrm{OH}\left[\left(\mathrm{Bu}_{3} \mathrm{Sn}\right)_{4} \mathrm{TPPS}\right]=0.15 \mu \mathrm{M}$ and $[\mathrm{SC} 6 \mathrm{OH}]=$ $0.75 \mu \mathrm{M}$. The cells were counted every $24 \mathrm{~h}$ for $72 \mathrm{~h}$ using the trypan blue exclusion test. For Nomarski microscopic images, the cells $\left(4 \times 10^{4}\right.$ cells/well in $400 \mu \mathrm{L}$ growth medium) were plated on an 8-well Lab-Tek II chamber slide, cultured for $24 \mathrm{~h}$, and treated as previously described. After each incubation, the cells were fixed, and the nuclei were stained with Hoechst 33342. Images were acquired with a Zeiss Axioskop 2 Plus microscope.

\section{RESULTS}

Porphyrin Tributyltin(IV) Derivative in Solution. The $\mathrm{Bu}_{3} \mathrm{Sn}(\mathrm{IV})^{+}$derivative of porphyrin (1) was synthesized as reported in the literature ${ }^{40}$ and was isolated in the solid state as a coordination polymer (Figure 1A). Analogously, 1 can be sketched with the formula presented in Figure 1B, which depicts a porphyrinoid moiety of the polymer.

Species 1 was dissolved in DMSO, EtOH, and $\mathrm{H}_{2} \mathrm{O}$ and was characterized via UV-vis, steady-state fluorescence, and measurements of anisotropy in various solvents (see Supporting Information, Figure $2 \mathrm{~A}, \mathrm{~B}$ ). The results are summarized in Table 1.

Species $\mathbf{1}$ is highly soluble in coordinating solvents such as DMSO and EtOH $(>50 \mu \mathrm{M})$, but less soluble in $\mathrm{H}_{2} \mathrm{O}(\leq 20 \mu \mathrm{M})$. In DMSO, 1 exhibits a much higher molar extinction coefficient than in $\mathrm{EtOH}$ or $\mathrm{H}_{2} \mathrm{O}$, in the range of $1.5-7 \mu \mathrm{M}\left(\varepsilon_{\text {DMSO }} \approx 4.2 \times\right.$ $\left.10^{5}>\varepsilon_{\mathrm{EtOH}} \approx 3.5 \times 10^{5} \approx \varepsilon_{\mathrm{H}_{2} \mathrm{O}} \approx 3.4 \times 10^{5} \mathrm{~cm}^{-1} \mathrm{M}^{-1}\right)$. The average static anisotropy $(\rho)$ is $\sim 0.02$ for $\mathbf{1}$ dissolved in DMSO, $\mathrm{EtOH}$, and $\mathrm{H}_{2} \mathrm{O}$ (see Supporting Information, Figure $2 \mathrm{~B}$ ). The ${ }^{1} \mathrm{H}$ NMR spectrum of $\mathbf{1}$ in DMSO- $d_{6}$ (Supporting Information, Figure 1) reveal the typical signals of porphyrin and tributyl chains, which integrate for one porphyrin core $\left(\right.$ TPPS $\left.^{4-}\right)$ 
Table 1. Spectroscopic Properties of 1: Molar Absorbitivity $\varepsilon$ and Anisotropy $\rho$ Measured at the Wavelength of the Absorbtion $(\lambda)$ and Emission Maxima $\left(\lambda_{\text {em }}\right)$, Respectively in Various Solvents

$\begin{array}{lcc}\text { solvent } & \lambda / \mathrm{nm}\left(\varepsilon / \mathrm{Mol}^{-1} \mathrm{~cm}^{-1}\right)^{a} & \lambda_{\mathrm{em}} / \mathrm{nm}(\rho)^{b} \\ \text { EtOH } & 416\left(3.5 \times 10^{5}\right) & 650(0.03) \\ & & 716(0.02) \\ \text { DMSO } & 420\left(4.2 \times 10^{5}\right) & 652(0.03) \\ & & 717(0.02) \\ \mathrm{H}_{2} \mathrm{O} & 413\left(3.4 \times 10^{5}\right) & 644(0.01) \\ & & 708(0.04)\end{array}$

${ }^{a}$ Standard error was $\cong 3 \%$ in all the determinations (five samples were analyzed at $1.5-7 \mu \mathrm{M}$ concentration range). ${ }^{b} \lambda_{\text {exc }}=516 \mathrm{~nm}$.

coordinating to four tributyl tin units $\left(\mathrm{Bu}_{3} \mathrm{Sn}^{+}\right)_{4}$ (species 2 in Figure 1C).

The speciation studies of $\mathbf{1}$ in aqueous solution were performed using spectrofluorimetric and potentiometric titrations and MALDI. The spectrofluorimetric spectra (see Supporting Information, Figure 3) were analyzed together with the potentiometric data using the Hyperquad $2008^{42}$ program, which enabled us to calculate the stability constants and fluorescence emission spectrum of each species using the experimental fluorescence intensities, the analytical concentrations of the reagents and the proposed chemical model as inputs. The emitting species were assigned via UV-vis (data not provided). The different speciation models were evaluated; however, the best outcomes were obtained when only the $\mathrm{M}_{4} \mathrm{~L}$ and $\mathrm{M}_{4} \mathrm{~L}(\mathrm{OH})_{4}$ species (the charges are omitted for simplicity) were considered.

The elaboration of the instrumental data (spectrofluorometric and potentiometric) enabled us to obtain the following overall stability constants for aqueous solutions of $1: \log \beta_{\mathrm{M}_{4} \mathrm{~L}}=21.48 \pm$ 0.09 and $\log \beta_{\mathrm{M}_{4} \mathrm{~L}(\mathrm{OH})_{4}}=3.66 \pm 0.06$ (the errors are reported as $\pm \mathrm{SD})$. The goodness of the adopted procedures for the speciation studies and of the obtained results, can be highlighted both from the low errors values associated to the overall stability constants of the $\mathrm{M}_{4} \mathrm{~L}$ and $\mathrm{M}_{4} \mathrm{~L}(\mathrm{OH})_{4}$ species, as well as from the statistical parameters of the titrations. In fact, independent of the titration taken into account, the elaboration of the experimental data (potentiometric and spectrofluorimetric) with the Hyperquad program, ${ }^{42}$ converged always within four iterations, with $\sigma$ ( \pm SD on the fit) values less than 800 , a very low value if we consider the fluorescence emission relative intensities. Moreover, the residuals observed between the experimental and calculated fluorescence intensity values were always, less than $4 \%$ for each titration point.

The equilibria that refer to the $\log \beta_{\mathrm{M}_{4} \mathrm{~L}(\mathrm{OH})_{i}}$ (for $\mathrm{OH}^{-}, i=0$ or 4) species can also be expressed as stepwise stability constants. For the $M_{4} L$ species, we can assume the equilibrium $M_{(i-1)} L+M$ $=\mathrm{M}_{i} \mathrm{~L}$ and calculate a mean stability constant of approximately 5.4 for each individual interaction between the metal ion fragment $\mathrm{Bu}_{3} \mathrm{Sn}^{+}$and the sulfonic group. For the $\mathrm{M}_{4} \mathrm{~L}(\mathrm{OH})_{4}$ species, we can consider the equilibrium $4 \mathrm{MOH}+\mathrm{L}=$ $\mathrm{M}_{4} \mathrm{~L}(\mathrm{OH})_{4}$, which has a mean stepwise stability constant of approximately 7.0. During the experimental data processing, the formation of other species was examined; however, they were systematically rejected by the computer program or their formation percentages under these experimental conditions were negligible, so they were considered minor species.
Figure 2 presents a distribution diagram of the species drawn at a ligand concentration of $1.7 \mu \mathrm{M}$. The formation of the $\mathrm{M}_{4} \mathrm{~L}$

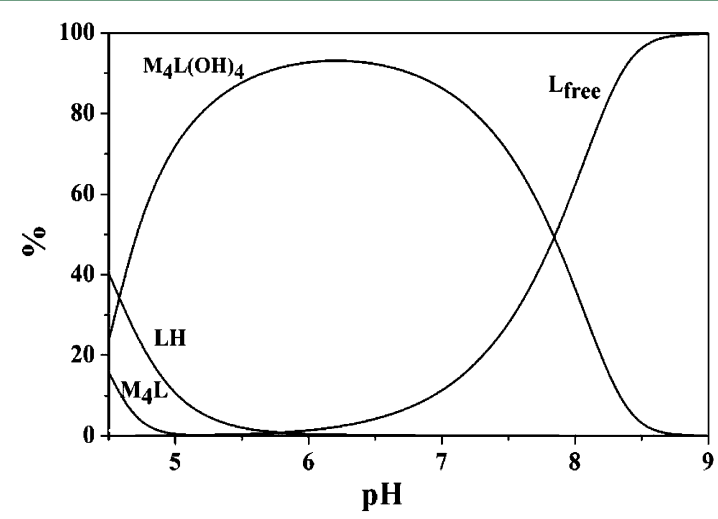

Figure 2. Distribution diagram of the species formed in $\mathbf{1}$ aqueous solution at $T=37^{\circ} \mathrm{C}\left([\mathbf{1}]=1.7 \mu \mathrm{M} ; \mathrm{M}=\mathrm{Bu}_{3} \mathrm{Sn}^{+} ; \mathrm{L}=\mathrm{TPPS}^{4-}\right)$.

species can be observed at $\mathrm{pH}$ values below 5.0, while, at physiological $\mathrm{pH}$, the most important species, derived from the hydrolysis of $\mathrm{M}_{4} \mathrm{~L}$, is $\mathrm{M}_{4} \mathrm{~L}(\mathrm{OH})_{4}$, which reaches approximately $75 \%$. At higher $\mathrm{pH}$ values, the free $\mathrm{TTPS}^{4-}\left(\mathrm{L}_{\text {free }}\right)$ species becomes predominant, while a maximum of $\sim 4 \%$ of the $\mathrm{M}(\mathrm{OH})_{2}$ species was formed at $\mathrm{pH} \sim 6.5$.

The negative MALDI-TOF spectrum (Figure 3) exhibits signals at $m / z 1800$ (detected as $\mathrm{M}^{-}$) and at $\mathrm{m} / z 1514$ (detected

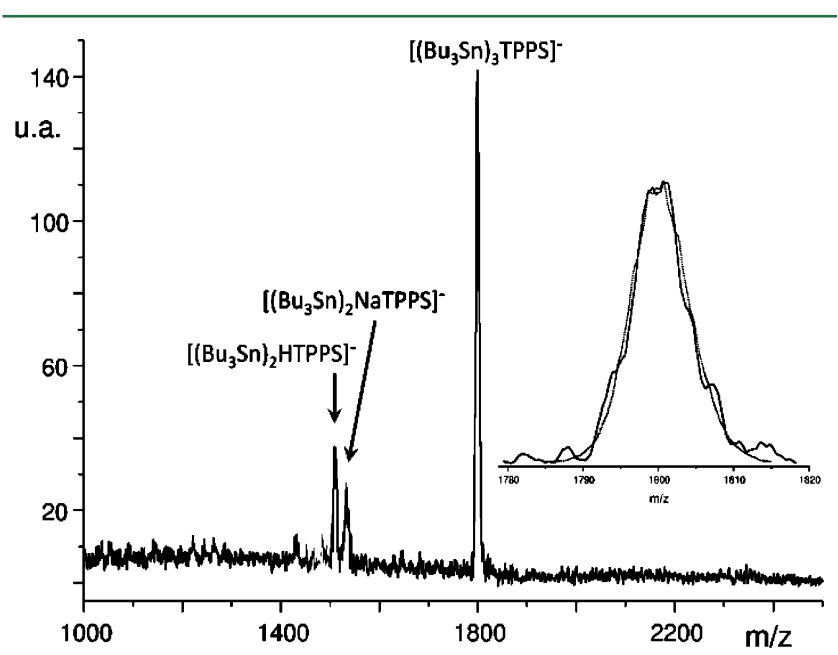

Figure 3. Negative MALDI-TOF mass spectrum of $\mathbf{1}$. In the inset, for comparison, the experimental isotopic cluster peaks of $\left(\mathrm{Bu}_{3} \mathrm{Sn}\right)_{3} \mathrm{TPPS}^{-}$ species $\left(\mathrm{M}^{-}\right.$, continuous line) and its simulated isotopic distribution (dotted line; fwhm $=1400$ ) is reported.

as $\mathrm{M}^{-}$), which are ascribed to the anionic moieties $\left(\mathrm{Bu}_{3} \mathrm{Sn}\right)_{3}$ TPPS $^{-}$and $\left(\mathrm{Bu}_{3} \mathrm{Sn}\right)_{2}(\mathrm{H}$ or $\mathrm{Na})$ TPPS $^{-}$and can be explained by a cationic $\left(\mathrm{Bu}_{3} \mathrm{Sn}^{+}\right)$moiety loss from species 2 during the MALDI desorption process. The inset of Figure 3 provides a comparison between the experimental isotopic cluster peaks at $m / z 1800$ (detected as $\mathrm{M}^{-}$) and the simulated isotopic distribution species (because of the isotopic composition, molecular species are detected in the mass spectra as clusters of peaks; to simplify their assignments, $m / z$ values reported in the text are referred to the first peak of each cluster, corresponding to the ion containing the most abundant isotope of each element present). 
Porphyrin/ACyD Nanoassemblies. Scheme 1 presents an approach for the formation of nanoassemblies of $\mathrm{SC} 6 \mathrm{OH}$ and 1 in aqueous solution.

The complexation between the $\left(\mathrm{Bu}_{3} \mathrm{Sn}\right)_{4} \mathrm{TPPS}$ and $\mathrm{SC} 6 \mathrm{OH}$ was investigated via $\mathrm{UV}$-vis and fluorescence emission spectroscopy, both in aqueous solution and in $\mathrm{PBS}$ at $\mathrm{pH}$ 7.4. Figure 4 A presents the UV-vis spectra in PBS. As in other studies, ${ }^{12}$ an
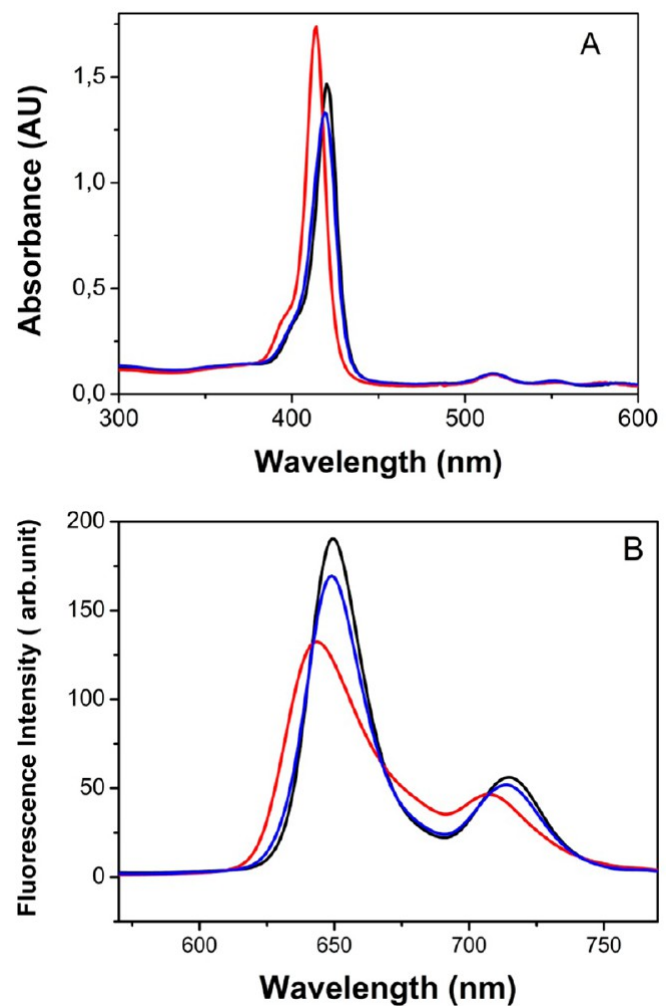

Figure 4. UV-vis spectra (A) and fluorescence emission spectra, $\lambda_{\text {exc }}=$ $516 \mathrm{~nm}(\mathrm{~B})$ of $\left(\mathrm{Bu}_{3} \mathrm{Sn}\right)_{4} \mathrm{TPPS}$ (red trace), $\left(\mathrm{Bu}_{3} \mathrm{Sn}\right)_{4} \mathrm{TPPS} / \mathrm{SC} 6 \mathrm{OH}$ at $1: 5$ (blue trace) and $1: 10$ (black trace) molar ratio in PBS $10 \mathrm{mM}(\mathrm{pH}=$ 7.4, $\left.\mathrm{T}=25^{\circ} \mathrm{C}\right)$. In all the dispersions $\left[\left(\mathrm{Bu}_{3} \mathrm{Sn}\right)_{4} \mathrm{TPPS}\right]$ was $5 \mu \mathrm{M}$.

excess of cyclodextrin was used as the complexing agent. Free $\left(\mathrm{Bu}_{3} \mathrm{Sn}\right)_{4}$ TPPS exhibits a B-band centered at $414 \mathrm{~nm}$, which is red- shifted at $420 \mathrm{~nm}$, exhibiting hypochromicity in the $\left(\mathrm{Bu}_{3} \mathrm{Sn}\right)_{4} \mathrm{TPPS} / \mathrm{SC} 6 \mathrm{OH}$ complexes (at both the 1:5 and 1:10 molar ratios). A slight hyperchromicity was registered as the carrier quantity increased from $1: 5$ to $1: 10$ porphyrin/cyclodextrin molar ratios. In addition, the Q-band region of the complexes reveals a small but detectable shift with respect to the free porphyrin.

The fluorescence emission bands of the free porphyrin exhibited maxima at 644 and $707 \mathrm{~nm}$, which shifted to 650 and $715 \mathrm{~nm}$, respectively, in the $\left(\mathrm{Bu}_{3} \mathrm{Sn}\right)_{4} \mathrm{TPPS} / \mathrm{SC} 6 \mathrm{OH}$ nanoassemblies (Figure 4B). At the lower drug/carrier molar ratio (1:10), the absorbance of the peculiar bands appeared slightly higher than at the higher porphyrin/cyclodextrin molar ratio (1:5).

The properties of the free ACyD and porphyrin/ACyD nanoassemblies (mean diameter, polydispersity index, and $\zeta$ potential) are reported in Table 2.

The SC6OH nanoassemblies exhibited a size distribution with a mean diameter of approximately $200 \mathrm{~nm}$ in water that increased slightly in $\mathrm{NaCl}$ medium. In addition, the $\zeta$-potential value was approximately $-6 \mathrm{mV}$ in $\mathrm{H}_{2} \mathrm{O}$ and increased in 0.9 wt \% $\mathrm{NaCl}$
Table 2. Properties of Nanoassemblies: Mean Diameter, Polydispersity Index (PDI), Zeta Potential ( $\zeta$ in TwiceDistilled Water and in Aqueous Solution of $\mathrm{NaCl} 0.9$ wt \% ${ }^{a}$

\begin{tabular}{|c|c|c|c|c|}
\hline sample & $\begin{array}{l}\text { dispersing } \\
\text { medium }\end{array}$ & $\begin{array}{l}\text { mean diameter } \\
(\mathrm{nm})\end{array}$ & PDI & $\begin{array}{l}\zeta(\mathrm{mV}) \\
( \pm \mathrm{SD})\end{array}$ \\
\hline \multirow[t]{2}{*}{ SC6OH } & $\mathrm{H}_{2} \mathrm{O}$ & 206.71 & 0.261 & $\begin{array}{l}-5.55 \\
( \pm 1.08)\end{array}$ \\
\hline & $\mathrm{NaCl} 0.9 \%$ & 224.42 & 0.282 & $\begin{array}{l}-1.55 \\
( \pm 1.21)\end{array}$ \\
\hline \multirow[t]{2}{*}{$\begin{array}{c}\left(\mathrm{Bu}_{3} \mathrm{Sn}\right)_{4} \mathrm{TPPS} / \\
\mathrm{SC} 6 \mathrm{OH}^{b, c, d}\end{array}$} & $\mathrm{H}_{2} \mathrm{O}$ & 228.43 & 0.264 & $\begin{array}{l}-15.3 \\
( \pm 2.50)\end{array}$ \\
\hline & $\mathrm{NaCl} 0.9 \%$ & 248.13 & 0.273 & $\begin{array}{l}-6.08 \\
( \pm 1.15)\end{array}$ \\
\hline
\end{tabular}

${ }^{a}$ Standard deviation (SD) was calculated on three different batches. ${ }^{b}\left(\mathrm{Bu}_{3} \mathrm{Sn}\right)_{4} \mathrm{TPPS} / \mathrm{SC} 6 \mathrm{OH}$ are at 1:5 molar ratio. ${ }^{c}$ Actual loading (mg of drug encapsulated per $100 \mathrm{mg}$ of nanoparticles) was 0.20 . ${ }^{d}$ Entrapment efficiency (ratio of actual to theoretical loading $\times 100$ ) was $67 \%$.

aqueous solution. The particle sizes differed slightly for the free $\mathrm{SC} 6 \mathrm{OH}$ and $\left(\mathrm{Bu}_{3} \mathrm{Sn}\right)_{4} \mathrm{TPPS} / \mathrm{SC} 6 \mathrm{OH}$ nanoassemblies, with the latter having a mean diameter of approximately $230 \mathrm{~nm}$ and a $\zeta$ potential of approximately $-15 \mathrm{mV}$. These values increased in aqueous $\mathrm{NaCl}$, and all particle distributions remained narrow (PDI values lower than 0.300 ).

Controlled Release Studies. The release profiles of the $\left(\mathrm{Bu}_{3} \mathrm{Sn}\right)_{4}$ TPPS species from the porphyrin/cyclodextrin nanoassemblies in PBS at $\mathrm{pH} 7.4$ were determined as reported in the literature. ${ }^{50}$ The results are presented in Figure 5.

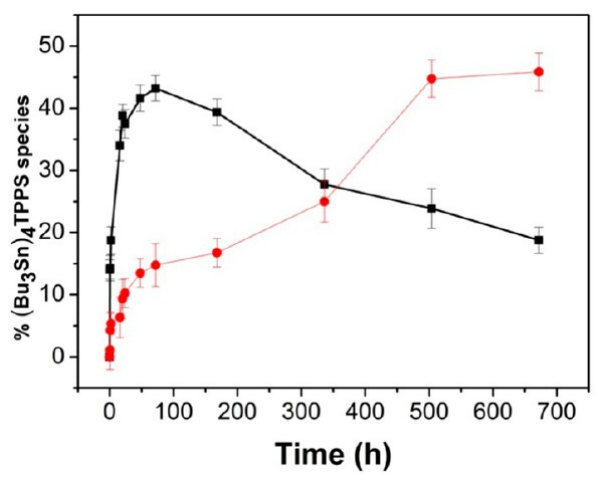

Figure 5. Release profile of $\left(\mathrm{Bu}_{3} \mathrm{Sn}\right)_{4} \mathrm{TPPS}$ from $\left(\mathrm{Bu}_{3} \mathrm{Sn}\right)_{4} \mathrm{TPPS} /$ $\mathrm{SC} 6 \mathrm{OH}$ nanoassemblies (red trace) and from free $\left(\mathrm{Bu}_{3} \mathrm{Sn}\right)_{4} \mathrm{TPPS}$ as control (black trace) in PBS $(20 \mathrm{mM})$ at $\left.\mathrm{pH} 7.4, T=37^{\circ} \mathrm{C}\right)$. Each value is the mean of three experiments $\pm \mathrm{SD}$.

In the absence of $\mathrm{ACyD}$, concentration equilibrium was reached between the compartments inside and outside the dialysis bag within $72 \mathrm{~h}$. Moreover, under these conditions, we observed that the release profile was affected by degradation phenomena. In contrast, the release from the porphyrin-loaded ACyD was significantly delayed.

Biological Studies. Intracellular Delivery. To verify the ability of A375 human melanoma cells to take up porphyrin delivered via $\mathrm{ACyD}$, these cells were treated for $2 \mathrm{~h}$ with either free $\left(\mathrm{Bu}_{3} \mathrm{Sn}\right)_{4}$ TPPS or $\left(\mathrm{Bu}_{3} \mathrm{Sn}\right)_{4}$ TPPS/SC6OH nanoassemblies with a porphyrin concentration of $5 \mu \mathrm{M}$. The intracellular localization of the $\left(\mathrm{Bu}_{3} \mathrm{Sn}\right)_{4}$ TPPS was revealed by its typical and well-detectable red fluorescence emission, as shown in Figure 6. Nuclear staining of these cells with fluorescent Hoechst dye demonstrated that the porphyrin species enter into the nucleus (Figure $6 \mathrm{C}^{4}$ ) and concentrate in the nucleoli (see arrows in 


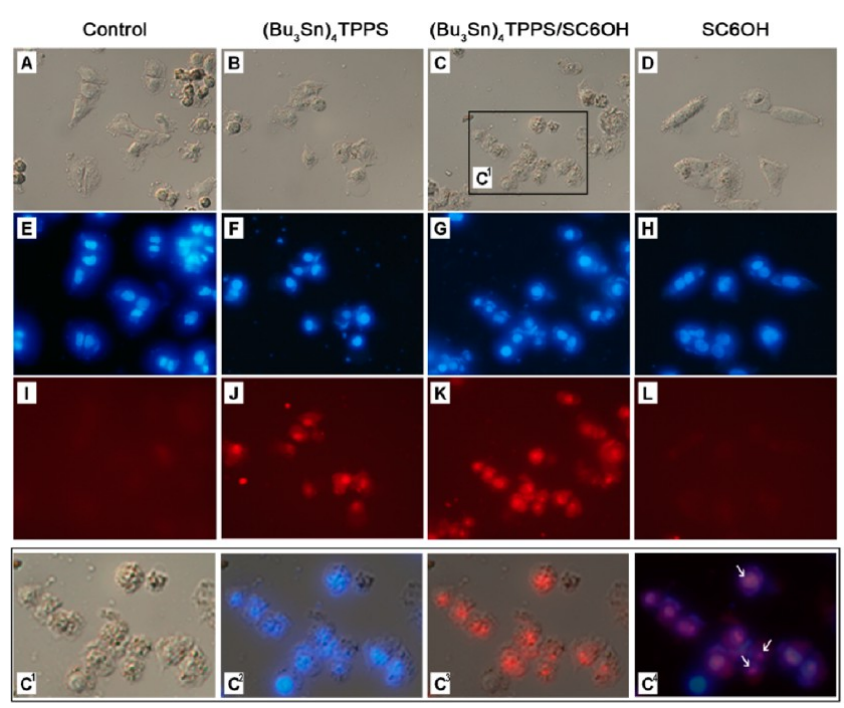

Figure 6. Intracellular delivery of $\left(\mathrm{Bu}_{3} \mathrm{Sn}\right)_{4}$ TPPS into A375 human melanoma cells by $\left(\mathrm{Bu}_{3} \mathrm{Sn}\right)_{4} \mathrm{TPPS} / \mathrm{SC} 6 \mathrm{OH}$ nanoassemblies at $1: 5$ molar ratio. Nomarski images (A-D); fluorescence images by Hoechst stain $(\mathrm{E}-\mathrm{H})$; fluorescence images by porphyrin species (I-L). Magnified images of rectangle in $C\left(C^{1}\right)$ and merged images $\left(C^{2}-\right.$ $\left.\mathrm{C}^{4}\right)$. Cells were treated with $\left(\mathrm{Bu}_{3} \mathrm{Sn}\right)_{4} \mathrm{TPPS}\left(\left[\left(\mathrm{Bu}_{3} \mathrm{Sn}\right)_{4} \mathrm{TPPS}\right]=5 \mu \mathrm{M}\right)$ $(\mathrm{B}, \mathrm{F}, \mathrm{J}),\left(\mathrm{Bu}_{3} \mathrm{Sn}\right)_{4} \mathrm{TPPS} / \mathrm{SC} 6 \mathrm{OH}\left(\left[\left(\mathrm{Bu}_{3} \mathrm{Sn}\right)_{4} \mathrm{TPPS}\right]=5 \mu \mathrm{M}\right.$, [SC6OH] $=25 \mu \mathrm{M})(\mathrm{C}, \mathrm{G}, \mathrm{K})$, or SC6OH $([\mathrm{SC} 6 \mathrm{OH}]=25 \mu \mathrm{M})(\mathrm{D}, \mathrm{H}, \mathrm{L})$ for $2 \mathrm{~h}$, then fixed and analyzed as described in Materials and Methods. Original magnification $40 \times$.

Figure $\left.6 \mathrm{C}^{4}\right)$. No clear fluorescence signal was observed below 5 $\mu \mathrm{M}\left(\mathrm{Bu}_{3} \mathrm{Sn}\right)_{4} \mathrm{TPPS}$ (data not presented). Even with the high $\left(\mathrm{Bu}_{3} \mathrm{Sn}\right)_{4} \mathrm{TPPS}$ (free or with $\mathrm{SC} 6 \mathrm{OH}$ ) concentration used in this experiment, after $2 \mathrm{~h}$ of treatment, the cells exhibited certain morphological changes, although their nuclei and nucleoli remained intact (Figures 6F,G, $\mathrm{C}^{4}$ ), most likely referring to an early stage of apoptosis. Moreover, the unloaded $\mathrm{SC} 6 \mathrm{OH}$ at the same concentration of the nanocomplex $(25 \mu \mathrm{M})$ does not appear to induce cytotoxicity because the cells exhibited a normal morphology (Figure 6D) similar to that of the untreated cells (Figure 6A).

Apoptosis and Cell-Growth Arrest of A375 Melanoma Cells. To determine the effectiveness of the porphyrin/ACyD nanosystem, the cells were treated for 24,48 , and $72 \mathrm{~h}$ with two doses of $\left(\mathrm{Bu}_{3} \mathrm{Sn}\right)_{4}$ TPPS/SC6OH. At a dose of $0.5 \mu \mathrm{M}$, both the free $\left(\mathrm{Bu}_{3} \mathrm{Sn}\right)_{4}$ TPPS and nanoassemblies induced a similar level of cell death, up $90-100 \%$, thus, producing identical cytotoxic effects (data not provided). In contrast, a lower dose $(0.25 \mu \mathrm{M})$ of free $\left(\mathrm{Bu}_{3} \mathrm{Sn}\right)_{4} \mathrm{TPPS}$ produced significantly less cell death (no more than $30 \%$ ), while the $\left(\mathrm{Bu}_{3} \mathrm{Sn}\right)_{4} \mathrm{TPPS} / \mathrm{SC} 6 \mathrm{OH}$ nanoassemblies still produced a highly cytotoxic effect on the A375 cells, as shown in Figure 7.

To investigate which cell death process was induced, we stained the cells with Hoechst dye to highlight the potential apoptotic nuclei. As shown in Figure 8G, the nuclei of the cells treated with the $\left(\mathrm{Bu}_{3} \mathrm{Sn}\right)_{4} \mathrm{TPPS} / \mathrm{SC} 6 \mathrm{OH}$ nanoassemblies $\left(\left[\left(\mathrm{Bu}_{3} \mathrm{Sn}\right)_{4} \mathrm{TPPS}\right]=0.25 \mu \mathrm{M}\right)$ exhibited morphological features of apoptosis, revealing a brighter chromatin than the nuclei of the untreated cells or the cells treated with free $\left(\mathrm{Bu}_{3} \mathrm{Sn}\right)_{4} \mathrm{TPPS}$ or unloaded $\mathrm{SC} 6 \mathrm{OH}$. The chromatin formed crescent and ring-like structures or, during the later stages of apoptosis, bright spherical beads.

A further reduction in the nanoassembly dose with $\left(\mathrm{Bu}_{3} \mathrm{Sn}\right)_{4} \mathrm{TPPS}$ at $0.15 \mu \mathrm{M}$ did not affect the cell death but did

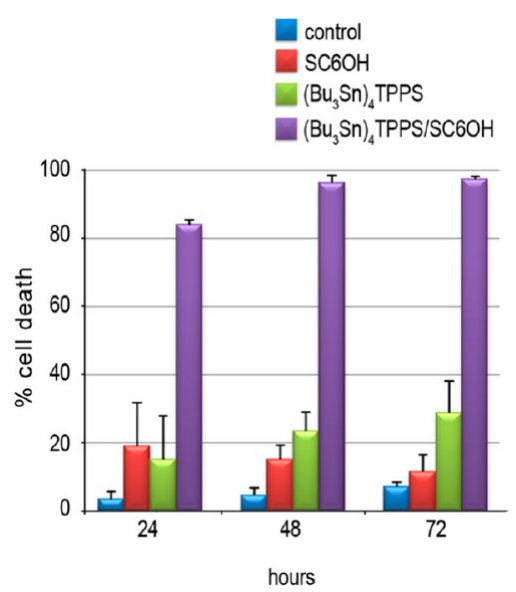

Figure 7. Cytotoxic effects of $\left(\mathrm{Bu}_{3} \mathrm{Sn}\right)_{4} \mathrm{TPPS} / \mathrm{SC} 6 \mathrm{OH}$ on $\mathrm{A} 375$ human melanoma cell viability. Cells were treated for 24,48 , and $72 \mathrm{~h}$ with $\left(\mathrm{Bu}_{3} \mathrm{Sn}\right)_{4} \mathrm{TPPS} / \mathrm{SC} 6 \mathrm{OH}$ nanoassemblies at $1: 5$ molar ratio $\left(\left[\left(\mathrm{Bu}_{3} \mathrm{Sn}\right)_{4} \mathrm{TPPS}\right]=0.25 \mu \mathrm{M},[\mathrm{SC} 6 \mathrm{OH}]=1.25 \mu \mathrm{M}\right), \mathrm{SC} 6 \mathrm{OH}$ $([\mathrm{SC} 6 \mathrm{OH}]=1.25 \mu \mathrm{M})$, or free $\left(\mathrm{Bu}_{3} \mathrm{Sn}\right)_{4}$ TPPS $\left(\left[\left(\mathrm{Bu}_{3} \mathrm{Sn}\right)_{4} \mathrm{TPPS}\right]=\right.$ $0.25 \mu \mathrm{M})$. Cell death was evaluated by trypan blue assay, using untreated cells as controls. Each data represent the percentage of cell death calculated from at least three separate experiments, for which the standard deviation is indicated.

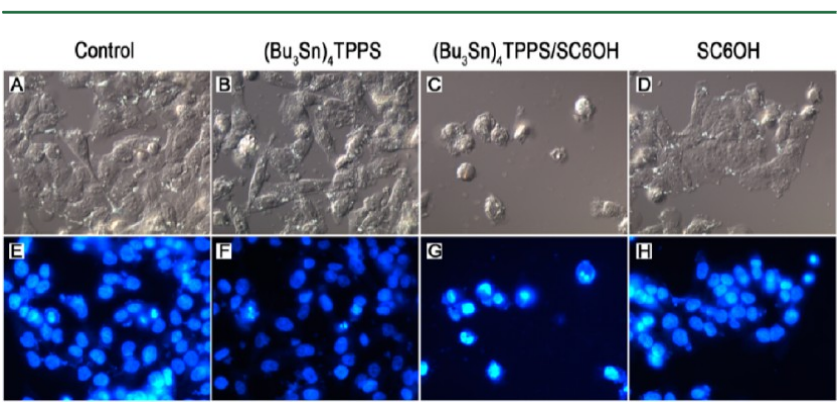

Figure 8. Nuclear morphology of A375 melanoma cells treated with $\left(\mathrm{Bu}_{3} \mathrm{Sn}\right)_{4} \mathrm{TPPS} / \mathrm{SC} 6 \mathrm{OH}$. Nomarski images (A-D); fluorescence images by Hoechst stain $(\mathrm{E}-\mathrm{H})$. Cells were treated for $24 \mathrm{~h}$ with free $\left(\mathrm{Bu}_{3} \mathrm{Sn}\right)_{4} \mathrm{TPPS}\left(\left[\left(\mathrm{Bu}_{3} \mathrm{Sn}\right)_{4} \mathrm{TPPS}\right]=0.25 \mu \mathrm{M}(\mathrm{B}, \mathrm{F}),\left(\mathrm{Bu}_{3} \mathrm{Sn}\right)_{4} \mathrm{TPPS} /\right.$ SC6OH nanoassemblies at 1:5 molar ratio $\left(\left[\left(\mathrm{Bu}_{3} \mathrm{Sn}\right)_{4} \mathrm{TPPS}\right]=0.25\right.$ $\mu \mathrm{M},[\mathrm{SC} 6 \mathrm{OH}]=1.25 \mu \mathrm{M})(\mathrm{C}, \mathrm{G})$, or SC6OH $([\mathrm{SC} 6 \mathrm{OH}]=1.25 \mu \mathrm{M})$ $(\mathrm{D}, \mathrm{H})$ and nuclei were observed after staining with fluorescent dye Hoechst 33342. Untreated cells were used as control (A, E).

arrest the A375 cell proliferation, especially after $48 \mathrm{~h}$ of treatment. In contrast, no effect was observed on cell growth with free $\left(\mathrm{Bu}_{3} \mathrm{Sn}\right)_{4} \mathrm{TPPS}$, regardless of treatment time (Figure 9).

The less prolific behavior of the A375 cells was associated with an evident morphological change at 48 and $72 \mathrm{~h}$ compared with the cells treated with free $\left(\mathrm{Bu}_{3} \mathrm{Sn}\right)_{4}$ TPPS or with unloaded $\mathrm{SC} 6 \mathrm{OH}$. After $24 \mathrm{~h}$ of treatment with the $\left(\mathrm{Bu}_{3} \mathrm{Sn}\right)_{4} \mathrm{TPPS} /$ SC6OH nanoassemblies $\left(\left[\left(\mathrm{Bu}_{3} \mathrm{Sn}\right)_{4} \mathrm{TPPS}\right]=0.15 \mu \mathrm{M}\right)$, the cells began to lengthen (Figure 10B), exhibiting an increasingly spindle-shaped phenotype with longer treatment time (Figure $10 \mathrm{H}, \mathrm{N}$ ). After $72 \mathrm{~h}$, most of the cells appeared fusiform- and starshaped with the dendrite-like projections (Figure 10N) that are characteristic of adult human melanocytes, that is, their primary cells.

\section{DISCUSSION}

Advanced melanoma remains associated with an extremely poor median survival and one of the most treatment-refractory malignancies. Many agents have been investigated for antitumor 

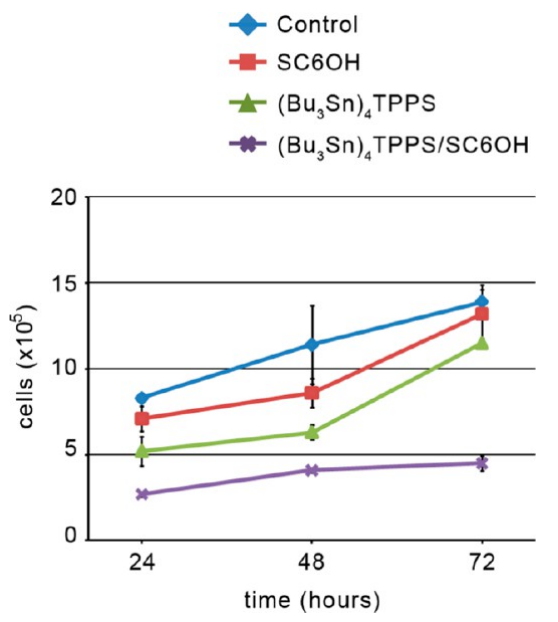

Figure 9. Effects of $\left(\mathrm{Bu}_{3} \mathrm{Sn}\right)_{4} \mathrm{TPPS} / \mathrm{SC} 6 \mathrm{OH}$ on $\mathrm{A} 375$ cell proliferation. Cells were treated with $\left(\mathrm{Bu}_{3} \mathrm{Sn}\right)_{4} \mathrm{TPPS} / \mathrm{SC} 6 \mathrm{OH}$ nanoassemblies at $1: 5$ molar ratio $\left(\left[\left(\mathrm{Bu}_{3} \mathrm{Sn}\right)_{4} \mathrm{TPPS}\right]=0.15 \mu \mathrm{M},[\mathrm{SC} 6 \mathrm{OH}]=0.75 \mu \mathrm{M}\right)$, $\mathrm{SC} 6 \mathrm{OH}([\mathrm{SC} 6 \mathrm{OH}]=0.75 \mu \mathrm{M})$, or free $\left(\mathrm{Bu}_{3} \mathrm{Sn}\right)_{4} \mathrm{TPPS}$ $\left(\left[\left(\mathrm{Bu}_{3} \mathrm{Sn}\right)_{4} \mathrm{TPPS}\right]=0.15 \mu \mathrm{M}\right)$ for 24,48 , and $72 \mathrm{~h}$, as described in Materials and Methods. Cell numbers were evaluated by trypan blue exclusion test at the end of treatments. Error bars represent the standard deviation of three separate experiments.

activity in melanoma; however, the current therapies have not overcome the high chemo-resistance of this aggressive and deadly malignancy. Thus, new therapeutic approaches to this disease are urgently needed.

As demonstrated and confirmed in this work, engineering $\left(\mathrm{Bu}_{3} \mathrm{Sn}\right)_{4}$ TPPS with a carrier as a supramolecular assembly appears to be a good approach to realize a successful nanotherapeutic, given its high effectiveness and interesting photo-independent effects on the proliferation of highly metastatic A375 melanoma cells. Moreover, previous studies demonstrated that in A375 melanoma cells, the $\left(\mathrm{Bu}_{3} \mathrm{Sn}\right)_{4} \mathrm{TPPS}$ compound decreases the expression of proteins involved in both tumorigenesis $^{51-53}$ and melanoma progression, ${ }^{54-56}$ such as $\beta$ catenin, c-myc, and snail, suggesting a probable reversion of tumor cells to a normal phenotype. ${ }^{36,37}$ Such proteins play a key role in the epithelial-to-mesenchymal transition (EMT). The EMT is an important developmental program by which cells switch from a polarized epithelial phenotype to a highly motile mesenchymal phenotype. In contrast, if stimulated within an adult organism, the EMT process promotes pathological conditions or tumor metastasis. ${ }^{57}$ Therefore, $\left(\mathrm{Bu}_{3} \mathrm{Sn}\right)_{4}$ TPPS may affect the restoration of the reverse EMT program, the mesenchymal-to-epithelial transition (MET), which could reduce the dedifferentiation and dissemination of tumor cells.

In previous studies, the observed effects were obtained at a lower $\left(\mathrm{Bu}_{3} \mathrm{Sn}\right)_{4}$ TPPS concentration than that used here; however, the compound was dissolved in DMSO, which is known to be an unsuitable environment for cells. This work involved $\left(\mathrm{Bu}_{3} \mathrm{Sn}\right)_{4} \mathrm{TPPS} / \mathrm{SC} 6 \mathrm{OH}$ nanoassemblies in water to yield the same effects of $\left(\mathrm{Bu}_{3} \mathrm{Sn}\right)_{4}$ TPPS at almost twice the concentration, below which the drug had no effect on melanoma cells (data not presented).

To relate the strong effect of the $\left(\mathrm{Bu}_{3} \mathrm{Sn}\right)_{4}$ TPPS dosed in DMSO on the typology of the active species in this solvent, spectroscopic characterizations were performed. Even though a quantitative speciation of $\mathbf{1}$ was not possible in this highcoordinating solvent, ${ }^{58}$ the ${ }^{1} \mathrm{H}$ NMR spectra strongly suggested the formation of $\mathbf{2}$ (see Figure 1), as indicated by the integrals of
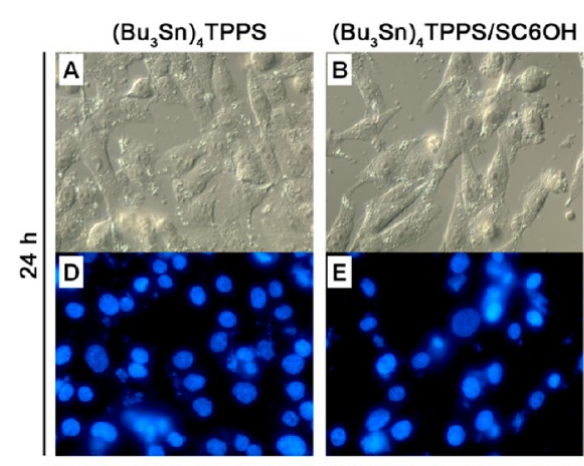

$\mathrm{SC} 6 \mathrm{OH}$
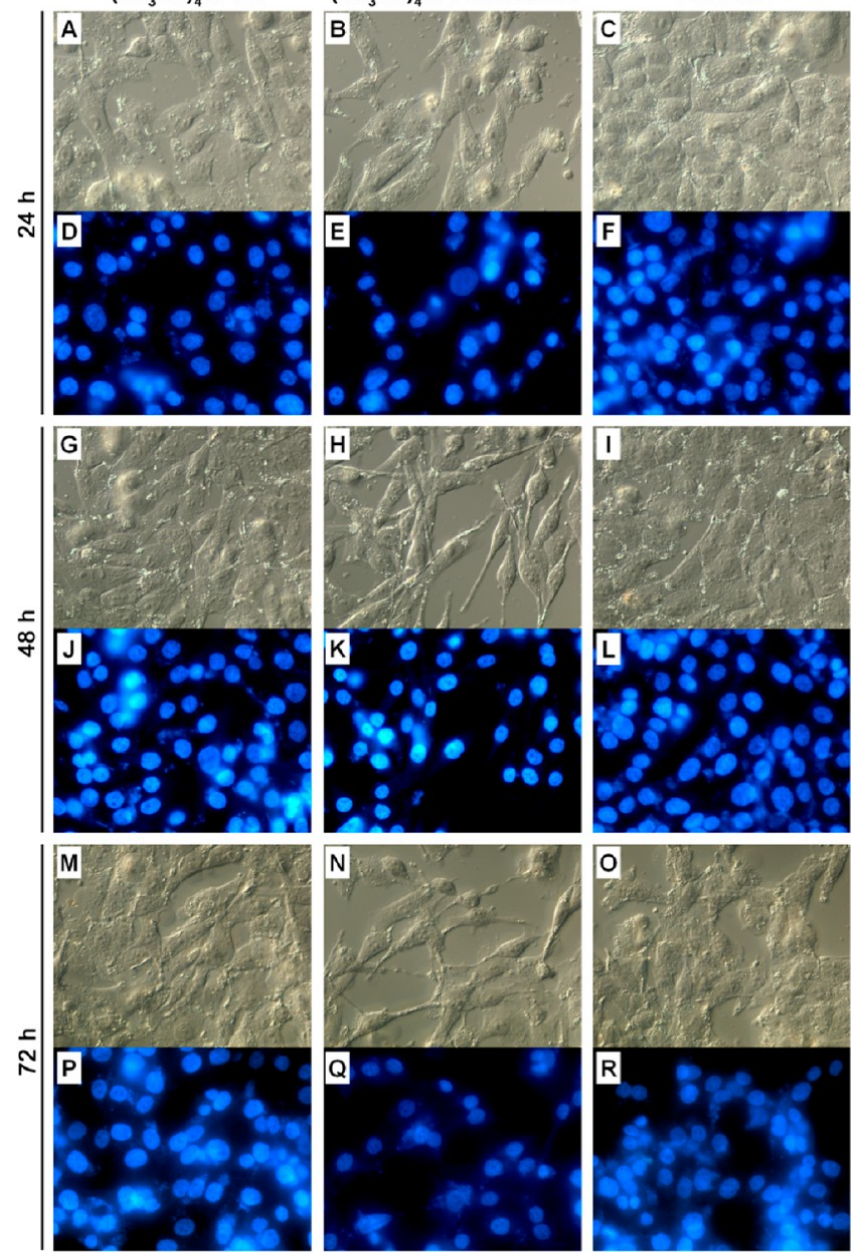

Figure 10. Effects of $\left(\mathrm{Bu}_{3} \mathrm{Sn}\right)_{4}$ TPPS/SC6OH on A375 cell morphology. Nomarski images (A-C; G-I; M-O); fluorescence images by Hoechst stain (D-F; J-L; P-R). Cells treated with $\left(\mathrm{Bu}_{3} \mathrm{Sn}\right)_{4} \mathrm{TPPS} / \mathrm{SC} 6 \mathrm{OH}$ nanoassemblies $\left(\left[\left(\mathrm{Bu}_{3} \mathrm{Sn}\right)_{4} \mathrm{TPPS}\right]=0.15 \mu \mathrm{M},[\mathrm{SC} 6 \mathrm{OH}]=0.75 \mu \mathrm{M}\right)$ (B, E, H, K, N, Q), SC6OH (C, F, I, L, O, R), or free $\left(\mathrm{Bu}_{3} \mathrm{Sn}\right)_{4}$ TPPS (A, $\mathrm{D}, \mathrm{G}, \mathrm{J}, \mathrm{M}, \mathrm{P})$ were observed after 24,48 , and $72 \mathrm{~h}$.

the porphyrin signals (Supporting Information, Figure 1). However, the sharpness of the signals excluded the presence of oligomeric/polymeric species (e.g., derivatives species of 2). A comparison of the spectroscopic properties of $\left(\mathrm{Bu}_{3} \mathrm{Sn}\right)_{4}$ TPPS in different coordinating solvents, DMSO, EtOH, and $\mathrm{H}_{2} \mathrm{O}$, helped to determine a rationale for the biological activity of $\mathbf{1}$. The UVvis and fluorescence emission spectra of 1 (Supporting Information, Figure 2A,B), both in DMSO and EtOH, confirmed the low tendency of porphyrin to self-aggregate at the investigated concentration $(1.5-7 \mu \mathrm{M})$. This behavior is most likely due to the coordinating effect of the solvent on tributyltin(IV), ${ }^{58}$ which destabilizes the formation of supramolecular porphyrin adducts and oligomeric species coordinated by sulfonate groups at the periphery of the porphyrin. Furthermore, the higher extinction values for 1 in DMSO compared with those in $\mathrm{EtOH}$, as reported in Table 1, rely on the improved solvent properties of the DMSO. The static anisotropy values for both the DMSO and ethanolic solutions of $\left(\mathrm{Bu}_{3} \mathrm{Sn}\right)_{4}$ TPPS are approximately 0.02 , suggesting the presence of free chromophoric species and the reduced presence of oligomeric supramolecular porphryin aggregates or interacting polymeric arrays. ${ }^{59}$ Therefore, in highly coordinating solvents 
(i.e., DMSO and EtOH), we propose the presence of monomeric derivatives of 1 (i.e., 2 in Figure 1C) in the investigated concentration range. In addition, in $\mathrm{H}_{2} \mathrm{O}$, the UV and fluorescence emission spectra (Supporting Information, Figure $2 A, B)$ and the anisotropy values agree with the formation of monomers at least up to $7 \mu \mathrm{M}$. The spectrofluorimetric and potentiometric titrations (see the distribution diagram in Figure 2 ) indicate the formation of both $\left(\mathrm{Bu}_{3} \mathrm{Sn}\right)_{4} \mathrm{TPPS}$ and $\left[\left(\mathrm{Bu}_{3} \mathrm{Sn}\right)_{4} \mathrm{TPPS}(\mathrm{OH})_{4}\right]^{4-}$; the latter is the species with the highest percentage formed $(\sim 75 \%)$ under physiological conditions. $^{60,61}$ The stability constants of the $\mathrm{M}_{4} \mathrm{~L}(\mathrm{OH})_{i}(i=0$ or 4) species indicate that they are not strong complexes; however, TPPS ${ }^{4-}$ is able to avoid the hydrolysis of the alkyltin cations over the entire $\mathrm{pH}$ range investigated, a fact that is observable with a low percentage of $\mathrm{M}(\mathrm{OH})_{2}$ formation.

Due to the high number of degrees of freedom in the system and the large number of data points collected, the low values of the statistical parameters for the titrations can be considered significant at a $95 \%$ confidence interval. Moreover, in this speciation, the contribution of species derivatives from small adducts of porphyrin was negligible at the investigated concentration $(\sim 2 \mu \mathrm{M})$. In addition, by simulating the preparative conditions in aqueous solution, the MALDI-TOF mass spectrometry investigations reveal the presence of the trisubstituted fragment $\left(\mathrm{Bu}_{3} \mathrm{Sn}\right)_{3}$ TPPS $^{-}$(detected as $\mathrm{M}^{-}$, see Figure 3), which is derived from monomer 2. In PBS, at $\mathrm{pH}=7.4$, the UV-vis and fluorescence emission spectra (Figure 4A,B) agree with the behavior of free $\mathbf{1}$ in $\mathrm{H}_{2} \mathrm{O}$ (with the prevalent formation of monomeric species 2). In PBS, at $\mathrm{pH} 7.4$, the complexation between the $\left(\mathrm{Bu}_{3} \mathrm{Sn}\right)_{4}$ TPPS species (e.g., 2 and hydroxyl derivatives of 2) and amphiphilic cyclodextrin was evident in the shifts of the unique absorption and emission bands.

The pophyrin/ACyD nanoassemblies proved to be highly stable in water and in the presence of $\mathrm{NaCl}(0.9 \mathrm{wt} \%)$ under ionic strength conditions simulating a physiological medium (see Table 2). Differences observed in either media for empty and loaded cyclodextrins can likely be attributed to the dependency between the $\zeta$-potential and the type and concentration of ions present in the aqueous medium and are strongly affected by the size and localization of the ions in the diffusive layer of each nanoparticle. $^{62,63}$ The absence of a burst release (Figure 5) indicated that the loaded drug was most likely encapsulated inside the nanoassemblies as supramolecular complexes with $\mathrm{ACyD}$. As with other polymeric core-shell nanosystems used against A375 melanoma cells, ${ }^{64}$ these results clearly address the selection of amphiphilic cyclodextrin to increase the benefit to the controlled release and protection via the degradation phenomena of hydrophobic tributyltin(IV) porphyrin derivatives. The entrapment of the $\left(\mathrm{Bu}_{3} \mathrm{Sn}\right)_{4}$ TPPS in $\mathrm{SC} 6 \mathrm{OH}$ nonionic amphiphilic cyclodextrin allowed the optimization of this drug as follows. First, the entrapment permits the availability of $\left(\mathrm{Bu}_{3} \mathrm{Sn}\right)_{4} \mathrm{TPPS}$ in water, a more suitable environment for cells, eliminating the possible toxic effects of the DMSO currently used in in vitro experiments. Second, the uptake/release via complexation with $\mathrm{ACyD}$ into melanoma cells is efficient, as indicated by the high and specific cytotoxicity and confirmed by the absence of cellular effects due to the unloaded $\mathrm{SC} 6 \mathrm{OH}$. Third, delivery via SC6OH allows the use of low $\left(\mathrm{Bu}_{3} \mathrm{Sn}\right)_{4} \mathrm{TPPS}$ concentrations to block A375 cell proliferation and induce a change of the cell morphology. Additional investigation into the effects of $\left(\mathrm{Bu}_{3} \mathrm{Sn}\right)_{4}$ TPPS on melanoma is needed; however, the entrapment of this porphyrin derivative into $\mathrm{ACyD}$ offers promising and interesting results, providing new insight into cancer research. In the near future, we aim to develop $\left(\mathrm{Bu}_{3} \mathrm{Sn}\right)_{4} \mathrm{TPPS} / \mathrm{SC} 6 \mathrm{OH}$ nanoassemblies to target specific markers expressed in melanoma cells and to validate the system efficacy in vivo using mouse xenograft models of human melanoma cells.

\section{CONCLUSIONS}

The proper design of nanoassemblies with improved water solubility based on complexes of the tributyltin(IV) derivative of meso-tetra(4-sulfonatophenyl)porphine with nonionic amphiphilic cyclodextrin allows species with high anticancer potential to be delivered into A375 melanoma cells under physiological conditions. Various instrumental techniques in aqueous solution have identified these active species as monomer derivatives from the $\left(\mathrm{Bu}_{3} \mathrm{Sn}\right)_{4}$ TPPS coordination polymer. Speciation studies highlight the formation of both $\left(\mathrm{Bu}_{3} \mathrm{Sn}\right)_{4}$ TPPS and $\left[\left(\mathrm{Bu}_{3} \mathrm{Sn}\right)_{4} \mathrm{TPPS}(\mathrm{OH})_{4}\right]^{4-}$, with the latter having the highest percentage of formation ( $75 \%)$ under physiological conditions. The cell uptake of monomeric tributyltin(IV) porphyrin incorporated in $\mathrm{ACyD}$ is highly efficient. Moreover, nanoassemblies based on the tributyltin(IV) porphyrin derivative/ $\mathrm{ACyD}$ complexes generate higher cytotoxicity than the free porphyrin derivative in water, inducing apoptotic cell death and, at lower concentrations, blocking cell proliferation in association with a change in cellular morphology.

\section{ASSOCIATED CONTENT}

\section{S Supporting Information}

${ }^{1} \mathrm{H}$ NMR spectrum of $\left(\mathrm{Bu}_{3} \mathrm{Sn}\right)_{4} \mathrm{TPPS}$ (Figure 1); UV-vis (Figura 2A) and fluorescence emission spectra (Figura 2B) of $\left(\mathrm{Bu}_{3} \mathrm{Sn}\right)_{4}$ TPPS in DMSO, EtOH, and $\mathrm{H}_{2} \mathrm{O}$. Experimental details on spectrofluorimetric and potentiometric studies; Spectrofluorimetric titrations of $\left(\mathrm{Bu}_{3} \mathrm{Sn}\right)_{4}$ TPPS at different $\mathrm{pH}$ values (Figure 3); Experimental details on MALDI-TOF mass spectrometry analysis. This material is available free of charge via the Internet at http://pubs.acs.org.

\section{AUTHOR INFORMATION}

\section{Corresponding Author}

*E-mail: antonino.mazzaglia@ismn.cnr.it; mariaassunta.costa@ pa.ibf.cnr.it.

\section{Notes}

The authors declare no competing financial interest.

- Previous address: CNR - Istituto di Biomedicina e Immunologia Molecolare 'Alberto Monroy', Via Ugo La Malfa 153, 90146 Palermo, Italy (M.A.C.).

\section{ACKNOWLEDGMENTS}

A.M. is grateful to Mr. Gaetano Irrera (CNR-ISMN) for technical assistance. MERIT-FIRB RBNE08YYBM (CNRISMN; CNR-IBIM); FaReBio di Qualità (CNR-IBIM, Laboratorio di Riferimento Farmaci innovativi - Modelli cellulari e murini e Studi funzionali); PON02 00665 (02_00355 2964193 HYPPOCRATES), EuroBioSAS-ŌP-009 (ICS project), ORPA07SLXE (Università degli Studi di Palermo).

\section{REFERENCES}

(1) Perret, F.; Parrot-Lopez, H. In Cyclodextrins in Pharmaceutics, Cosmetics, and Biomedicine: Current and Future Industrial Applications; Bilensoy, E., Ed.; John Wiley \& Sons, Inc.: Hoboken, NJ, U.S.A., 2011; pp 197-233 and ref therein.

(2) Lombardo, D.; Longo, A.; Darcy, R.; Mazzaglia, A. Langmuir 2004, $20,1057-1064$. 
(3) Villari, V.; Mazzaglia, A.; Darcy, R.; O’Driscoll, C. M.; Micali, N. Biomacromolecules 2013, 14, 811-817.

(4) Quaglia, F.; Ostacolo, L.; Mazzaglia, A.; Villari, V.; Zaccaria, D.; Sciortino, M. T. Biomaterials 2009, 30, 374-382.

(5) Ferro, S.; Jori, G.; Sortino, S.; Stancanelli, S.; Nikolov, P.; Tognon, G.; Ricchelli, F.; Mazzaglia, A. Biomacromolecules 2009, 10, 2592-2600.

(6) Voskuhl, J.; Kauscher, U.; Malte Gruener, M.; Frisch, H.; Wibbeling, B.; Strassert, C. A.; Ravoo, B. J. Soft Matter 2013, 9, $2453-2457$.

(7) Mazzaglia, A.; Monsù Scolaro, L.; Mezzi, A.; Kaciulis, S.; De Caro, T.; Ingo, G. M.; Padeletti, G. J. Phys. Chem. C 2009, 113, 12772-12777.

(8) Kandoth, N.; Vittorino, E.; Sciortino, M. T.; Parisi, T.; Colao, I.; Mazzaglia, A.; Sortino, S. Chem.-Eur. J. 2012, 6, 1684-1690.

(9) Trapani, M.; Romeo, A.; Parisi, T.; Sciortino, M. T.; Patanè, S.; Villari, V.; Mazzaglia, A. RSC Adv. 2013, 3, 5607-5614.

(10) Díaz-Moscoso, A.; Guilloteau, N.; Bienvenu, C.; Méndez-Ardoy, A.; Jiménez Blanco, J. L.; Benito, J. M.; Le Gourriérec, L.; Di Giorgio, C.; Vierling, P.; Defaye, J.; Mellet, C. O.; García Fernández, J. M. Biomaterials 2011, 32, 7263-7273.

(11) Mazzaglia, A.; Valerio, A.; Villari, V.; Rencurosi, A.; Lay, L.; Spadaro, S.; Monsù Scolaro, L.; Micali, N. New J. Chem. 2006, 30, 16621668.

(12) Mazzaglia, A.; Valerio, A.; Micali, N.; Villari, V.; Quaglia, F.; Castriciano, M. A.; Monsù Scolaro, L.; Giuffré, M.; Siracusano, G.; Sciortino, M. T. Chem. Commun. (Cambridge, U. K.) 2011, 47, 91409142.

(13) Sortino, S.; Petralia, S.; Darcy, R.; Donohue, R.; Mazzaglia, A. New J. Chem. 2003, 30, 1662-1668.

(14) Ravoo, B. J.; Jacquier, J.-C.; Wenz, G. Angew. Chem., Int. Ed. 2003, 42, 2066-2070.

(15) Scala, A.; Cordaro, M.; Mazzaglia, A.; Risitano, F.; Venuti, A.; Sciortino, M. T.; Grassi, G. MedChem Comm 2011, 2, 172-175.

(16) Memisoglu-Bilensoy, E.; Vural, I.; Bochot, A.; Renoir, J. M.; Duchene, D.; Hincal, A. A. J. Controlled Release 2005, 104, 489-496.

(17) Bilensoy, E.; Gurkaynak, O.; Ertan, M.; Sen, M.; Hincal, A. A. J. Pharm. Sci. 2008, 97, 1519-1529.

(18) Basu, S.; Harfouche, R.; Soni, S.; Chimote, G.; Raghunath A. Mashelkara, R. A.; Sengupta, S. Proc. Natl. Acad. Sci. U.S.A. 2009, 106, 7957-7961.

(19) Ding, B.; Wu, X.; Fan, W.; Wu, Z.; Gao, J.; Zhang, W.; Ma, L.; Xiang, W.; Zhu, Q.; Liu, J.; Ding, X.; Gao, S. Int. J. Nanomed. 2011, 6, 1991-2005.

(20) Rezler, E. R.; Khan, D. R.; Lauer-Fields, J.; Cudic, M.; BaronasLowell, D.; Fields, G. B. J. Am. Chem. Soc. 2007, 129, 4961-4972.

(21) Şoica, C.; Dehelean, C.; Danciu, C.; Wang, H. M.; Wenz, G.; Ambrus, R.; Bojin, F.; Anghel, M. Int. J. Mol. Sci. 2012, 13, 1499215011 .

(22) Michel, D.; Chitanda, J. M.; Balogh, R.; Yang, P.; Singh, J.; Das, U.; El-Aneed, A.; Dimmock, J.; Verrall, R.; Badea, I. Eur. J. Pharm. Biopharm. 2012, 81, 548-556.

(23) Forsea, A. M.; Del Marmol, V.; de Vries, E.; Bailey, E. E.; Geller, A.

C. Br. J. Dermatol. 2012, 167, 1124-1130.

(24) Little, E. G.; Eide, M. J. Dermatol. Clin. 2012, 30, 355-361.

(25) Agarwala, S. S.; Keilholz, U.; Gilles, E.; Bedikian, A. Y.; Wu, J.; Kay, R.; Stein, C. A.; Itri, L. M.; Suciu, S.; Eggermont, A. M. Eur. J. Cancer 2009, 45, 1807-1814.

(26) Su, P. J.; Chen, J. S.; Liaw, C. C.; Chang, H. K.; Wang, H. M.; Yang, T. S.; Lin, Y. C.; Liau, C. T.; Yang, H. Y.; Yeh, K. Y.; Ho, M. M.; Chang, N. J.; Wang, C. H.; Chang, J. W. Chang Gung Med. J. 2011, 34, 478-486.

(27) Mangana, J.; Levesque, M. P.; Karpova, M. B.; Dummer, R. Expert Opin. Invest. Drugs 2012, 21, 557-568.

(28) Verschraegen, C. Cancer Manag. Res. 2012, 4, 1-8.

(29) Sharma, A.; Shah, S. R.; Illum, H.; Dowell, J. Drugs 2012, 72, 2207-2222.

(30) Agostinis, P.; Berg, K.; Cengel, K. A.; Foster, T. H.; Girotti, A. W.; Gollnick, S. O.; Hahn, S. M.; Hamblin, M. R.; Juzeniene, A.; Kessel, D.; Korbelik, M.; Moan, J.; Mroz, P.; Nowis, D.; Piette, J.; Wilson, B. C.; Golab, J. C. A. Cancer J. Clin. 2011, 61, 250-281.
(31) Moffatt-Bruce, S. J. Natl. Compr. Cancer Network 2012, 10, S2730.

(32) O'Connor, A. E.; Gallagher, W. M.; Byrne, A. T. Photochem. Photobiol. 2009, 85, 1053-1074.

(33) Zeitouni, N. C.; Oseroff, A. R.; Shieh, S. Mol. Immunol. 2003, 39, $1133-1136$.

(34) Ma, L. W.; Nielsen, K. P.; Iani, V.; Moan, J. J. Environ. Pathol. Toxicol. Oncol. 2007, 26, 165-172.

(35) Costa, M. A.; Pellerito, L.; Izzo, V.; Fiore, T.; Pellerito, C.; Melis, M.; Musmeci, M. T.; Barbieri, G. Cancer Lett. 2006, 238, 284-294.

(36) Costa, M. A.; Gulino, L.; Pellerito, L.; Fiore, T.; Pellerito, C.; Barbieri, G. Oncol. Rep. 2009, 21, 593-599.

(37) Costa, M. A.; Zito, F.; Emma, M. R.; Pellerito, L.; Fiore, T.; Pellerito, C.; Barbieri, G. Int. J. Oncol. 2011, 38, 693-700.

(38) Rück, A.; Steiner, R. Minim. Invasive Ther. Allied Technol. 1998, 7, 503-509.

(39) Mazzaglia, A.; Donohue, R.; Ravoo, B. J.; Darcy, R. Eur. J. Org. Chem. 2001, 1715-1721.

(40) Pellerito, A.; Fiore, T.; Giuliani, A. M.; Maggio, F.; Pellerito, L.; Mansueto, C. Appl. Organomet. Chem. 1997, 11, 707-719.

(41) Lackowicz, J. R. Principles of Fluorescence Spectroscopy; Kluwer Academic, Plenum Publisher: New York, 1999.

(42) Gans, P.; Sabatini, A.; Vacca, A. Talanta 1996, 43, 1739-1753.

(43) Farajtabar, A.; Gharib, F.; Jammat, P.; Safari, N. J. Chem. Eng. Data 2008, 53, 350-354.

(44) Monsù Scolaro, L.; Romeo, A.; Castriciano, M. A.; Micali, N. Chem. Commun. 2005, 24, 3018-3020.

(45) Foti, C.; Gianguzza, A.; Milea, D.; Sammartano, S. Appl. Organomet. Chem. 2002, 16, 34-43.

(46) Kussmann, M.; Nordhoff, E.; Rahbek-Nielsen, H.; Haebel, S.; Rossel-Larsen, M.; Jakobsen, L.; Gobom, J.; Mirgorodskaya, E.; KrollKristensen, A.; Palm, L.; Roepstorff, P. J. Mass Spectrom. 1997, 32, $593-$ 601.

(47) Mineo, P.; Vitalini, D.; Scamporrino, E. Rapid Commun. Mass Spectrom. 1999, 13, 2511-2517.

(48) Mazzaglia, A. In Cyclodextrins in Pharmaceutics, Cosmetics, and Biomedicine Current and Future Industrial Applications; Bilensoy, E., Ed.; John Wiley and Sons: New York, 2011; pp 343-361.

(49) Giard, D. J.; Aaronson, S. A.; Todaro, G. J.; Arnstein, P.; Kersey, J. H.; Dosik, H.; Parks, W. P. J. Natl. Cancer Inst. 1973, 51, 1417-1423.

(50) Bondì, M. L; Craparo, E. F.; Picone, P.; Di Carlo, M.; Di Gesù, R.; Capuano, G.; Giammona, G. Curr. Nanosci. 2010, 6, 439-445.

(51) Peifer, M.; Polakis, P. Science 2000, 287, 1606-1609.

(52) Boxer, L. M.; Dang, C. V. Oncogene 2001, 20, 5595-5610.

(53) Medici, D.; Hay, E. D.; Olsen, B. R. Mol. Biol. Cell 2008, 19, 48754887.

(54) Tucci, M. G.; Lucarini, G.; Brancorsini, D.; Zizzi, A.; Pugnaloni, A.; Giacchetti, A.; Ricotti, G.; Biagini, G. Br. J. Dermatol. 2007, 157, $1212-1216$

(55) Hu, G.; Wei, Y.; Kang, Y. Clin. Cancer Res. 2009, 15, 5615-5620.

(56) Massoumi, R.; Kuphal, S.; Hellerbrand, C.; Haas, B.; Wild, P.; Spruss, T.; Pfeifer, A.; Fässler, R.; Bosserhoff, A. K. J. Exp. Med. 2009, 206, 221-232.

(57) Thiery, J. P. Curr. Opin. Cell Biol. 2003, 15, 740-746.

(58) Shankar, R.; Archana Jain, R.; Kociok-Köhn, G.; Molloy, K. C. Inorg. Chem. 2011, 50, 1339-1350.

(59) Castriciano, M A; Romeo, A.; Monsù Scolaro, L. J. Porph. Phthal. 2005, 6, 431-438.

(60) Pellerito, L.; Nagy, L. Coord. Chem. Rev. 2002, 224, 111-150.

(61) El-Sherif, A. A. J. Solution Chem. 2012, 41, 1522-1554.

(62) Bondì, M. L.; Montana, G.; Craparo, E. F.; Di Gesù, R.; Giammona, G.; Bonura, A.; Colombo, P. Int. J. Nanomed. 2011, 6, $2953-2962$

(63) Bondì, M. L.; Craparo, E. F.; Giammona, G.; Drago, F. Nanomedicine 2010, 5, 25-32.

(64) Maglio, G.; Nicodemi, F.; Conte, C.; Palumbo, R.; Tirino, P.; Panza, E.; Ianaro, A.; Ungaro, F.; Quaglia, F. Biomacromolecules 2011, $12,4221-4229$. 